\title{
Do You Sincerely Want To Be Radical?
}

\author{
Phillip E. Johnson*
}

Eleven o'clock news. A gauzy-bearded boy, his face pressed so hard against the camera the focus cannot be maintained, screams, "Off the pigs! All power to the people!"

An unseen interviewer mellifluously asks him, "How would you describe the goals of your organizations?"

"Destruction of existing repressive structures. Social control of the means of production."

"Could you tell our viewing audience what you mean by 'means of production'?"

The camera is being jostled; the living room, darkened otherwise, flickers. "Factories. Wall Street. Technology. All that. A tiny clique of capitalists is forcing pollution down our throats, and the SST and the genocide in Vietnam and in the ghettos. All that."

"I see. Your aim, then, by smashing windows, is to curb a runaway technology and create the basis for a new humanism."

The boy looks off-screen blearily, as the camera struggles to refocus him. "You being funny? You'll be the first up against the wall, you-" And the blip showed that the interview had been taped. $^{1}$

We grew up in an era when it was virtually impossible to feel comfortable with the status quo, an era when it was not so easy to dismiss a "radical" critique with a clubbish word of derision, an era when hope for a newer world came naturally. ${ }^{2}$

I view the Critical Legal Studies ("CLS") movement as an outsider who does not share its assumptions or its purposes. For those who are like me in this respect, which is to say most people, the first

* Professor of Law, University of California, Berkeley; Visiting Professor of Law 1982-83, Emory University.

I am grateful to numerous colleagues at Berkeley and Emory who criticized an earlier draft of this paper. Dean Thomas Morgan not only provided a congenial working environment for me at Emory, but also offered some characteristically cogent suggestions for improving the manuscript.

1. J. UPDIKE, RABBIT REDUX (1971) (set in 1969).

2. Parker, The Past of Constitutional Theory-And Its Future, 42 OHIO ST. L.J. 223, 257 (1981) Richard Davies Parker, born in 1945, is a Harvard Law School professor and a CCLS member.). 
question that such a movement poses is whether we ought to take it seriously. Should we regard the CLS movement as a genuine radical challenge to the dominant liberalism of legal thinking, or as a pathological phenomenon, a Peter Pan syndrome? We expect adolescents to come up with grand criticisms of the existing order without proposing a realistic alternative, but by the time one graduates from law school, or at least by the time one achieves tenure on a law school faculty, we generally expect the former adolescent to have developed a willingness to come to terms with reality. And yet here is a movement composed of supposedly radical law professors who proudly proclaim themselves to be "utopian," and whose positive program seems to contain nothing more substantial than an instinctive dislike for "domination" and "hierarchy."

Even the fundamental premise of their criticism- that purportedly neutral legal doctrine operates to mystify and legitimate existing patterns of domination and subordination-is quite literally the oldest argument in the book, and its paternity is not encouraging. " 'You will not die,' the serpent told Eve as they eyed the forbidden fruit, '[f]or God knows that when you eat of it your eyes will be opened, and you will be like God, knowing good and evil.'"3 No doubt any legal order incorporates a certain amount of domination, and no doubt theory often provides some justification for existing practices. What of it? If this is all the Critical scholars have to say, why should we bother reading them?

We are justly criticized if we fail to read a radical critique sympathetically, if we seize upon its weak points and fail to appreciate what it has to say. But just what does CLS have to say? And even prior to that question, what is the common element that makes CLS a unified movement? Unquestionably, the Critical legal scholars aim at being radical, but theirs is not the kind of radicalism that involves a party line and organizational discipline. The Conference on Critical Legal Studies ("CCLS") is said to be "fragmented" and to lack a "definitive methodological approach." The letter from the Stanford Law Review inviting me to participate in this Symposium even questioned "if indeed there is a coherent body of thought parading under that

3. Genesis 3:4-5 (rev. standard version).

4. Paul Brest has described the CLS movement as "small and fragmented." Brest, Interpretation and Interest, 34 STAN. L. REV. 765, 765 (1982).

5. Note, 'Round and 'Round the Bramble Bush: From Legal Realism to Critical Legal Scholarship, 95 HARV. L. REV. 1669, 1669 n.3 (1982). For a participant's well written explanation of the purpose of the CLS movement, see Gordon, New Developments in Legal Theory, in THE POLItics of LaW: A PROGRessive CRITIQUe 28 (D. Kairys ed. 1982). 
name [(CLS)]." After reading a substantial number of articles, I would say that enough common elements exist to permit intelligent discussion of the movement as a whole. There is a common Critical viewpoint that is either stated or assumed throughout the literature, although individual members of the movement might express it in different ways on different subjects. We can generalize about Critical legal scholarship in the same way that we can generalize about any intellectual movement, bearing in mind that generalizations always overlook some individual differences.

Part I of this article describes and analyzes what I see as the general characteristics of Critical legal scholarship; I shall pay particular attention to an influential article by Professor Duncan Kennedy of the Harvard Law School. A major feature of Critical scholarship is its preoccupation with discrediting a school of thought that seems to be dominant in academic legal circles at the present time, a viewpoint that I call liberal rationalism. Part II discusses liberal rationalism and its limitations. Drawing attention to those limitations has been a major accomplishment of Critical scholarship. Part Three describes the inadequate response of the Critical scholars to their own critique of liberal rationalism and the reasons for their inability to suggest an alternative to a way of thought that they decisively reject.

The Critical scholars sincerely want to be radicals: Indeed, some of them formed their standards of right and wrong in a counterculture that associated radical politics with goodness itself and identified liberalism with "selling out." They are also aware that the existing legal order is not as securely founded upon reason as some people like to pretend. Unfortunately, they do not have a radical alternative to propose. Their strategy in this awkward situation is to retreat into a mystical utopianism that is couched in political language but in fact has little to do with politics. The "incoherence" of liberalism is their incoherence, its "failure" their failure. Critical legal writing provides a way of sounding like a radical when you don't know how to be one.

\section{The Critical Viewpoint: Alienation, Demystification, AND UTOPIANISM}

The general inspiration and title for the CLS movement come from the tradition of Critical Marxism derived from the early writing of Karl Marx, ${ }^{6}$ the most important academic manifestation of which

6. Duncan Kennedy has recommended A. Gouldner, The Two Marxisms (1980), as an introduction to what he calls "fancy theory." Gouldner divides Marxism into two tradi- 
has been the "Critical Theory" of writers such as Max Horkheimer, Jurgen Habermas, and Herbert Marcuse. This "Frankfurt School" of German social philosophy used Hegelian, Marxist, Freudian, and Existentialist thought to expose the disguised oppressive elements and contradictions in "capitalist" society, ${ }^{7}$ with the aim of liberating humanity from oppression. ${ }^{8}$ Following a period of neglect, Critical Theory had a powerful renaissance among students and intellectuals in the turbulent years of the late Sixties. The CCLS brings this perspective to legal scholarship.

Critical Theory is a complex and controversial subject, and not one on which I feel competent to make fine distinctions, even if I had the space and time. Fortunately, there is no need to go into detail, because what the CLS movement has borrowed from Critical Theory seems to be more a general attitude than any set of specific propositions. Critical Theory attempted to fuse the work of a number of important thinkers, especially Freud and Marx, into an ambitious

tions, "Scientific" and "Critical." Scientific Marxism" (sometimes called "vulgar" or "classical" Marxism) is the deterministic theory developed in Marx's later writings, especially Das Kapital. According to Scientific Marxism, capitalism will inevitably succumb to its own contradictions, eventually giving way to socialism. On the other hand. Critical Marxism stresses the ability of determined individuals to alter the course of history by courageous action; it therefore sees revolutionary liberation as a possibility at any time, whether or not capitalism has reached the brink of collapse. It also views revolutionary consciousness as something to be achieved rather than as something that the proletariat automatically develops. Due to the perverse refusal of history to follow the course laid down in Marx's later writing, Critical Marxism has now become the dominant strand of the Marxist tradition. Famous names in the rolls of Critical Marxism include Lukacs, Gramsci, Sartre, Castro, and Mao.

7. I use the term "capitalist" because the Critical theorists and Critical legal scholars use it to describe the mixed economies and democratic political institutions of Western Europe and North America. This term is more argumentative than descriptive, however. These countries could just as accurately be described as "socialist" because their governments participate actively in economic matters with a view to influencing the distribution of wealth and the allocation of resources.

8. The cultural attitude that lay behind this enterprise is described in G. FRIEDMAN, The Political Philosophy of the Frankfurt School 18 (1981):

What the intellectual loathes far more than human suffering is human indifference to it. The philistinism of the bourgeois sensibility and not bourgeois practice itself is what nauseates intellectuals and drives them to their radicalism.

This repugnance lies at the heart of the Frankfurt School. Their project, in part, was to teach the children of the bourgeoisie, sent to them to become ornaments to their dull fathers' lives, to take arms against the emptiness of those lives. As the true progenitors of the children's revolt of the 1960's, the Frankfurt School took on as its political project an attack on bourgeois philistinism. Their loathing was not for poverty but for the affluent society, not for brute suffering but for subliminal dehumanization. Aesthetics and not economics was their political arena. This is not said to denigrate the Frankfurt School. On the contrary, it is praise for their singular insight into the true rather than mythical functioning of politics in the twentieth century. 
critique of modern society. To the extent that its intent was revolutionary, it differed from classical Marxism in assigning the vanguard role to the disaffected intellectual (like Marx himself) rather than to the industrial worker. ${ }^{9}$ It declared that the chains that most strongly bind an oppressed class are ideological in nature, i.e., the habits of thought that tend to make both the master and the slave accept the existing situation as justified or inevitable. Critical Theory aimed to expose the irrationality and contingency of conventional thought, and thus to free people to conceive of new possibilities for social liberation. Critical legal scholarship similarly sees conventional legal scholarship as playing an apologetic role for oppression in contemporary American society, either by rationalizing existing legal practices or by proposing specific reforms based on the premise that those practices are fundamentally reasonable if suitably reformed. This underlying assumption of rationality is the focus of Critical legal thought. ${ }^{10}$

9. The development of Critical Theory is described in G. FRIEDMAN, supra note 8, at 234 (footnotes omitted):

The earlier formulations of Critical Theory offered rather traditional views of class. Acknowledging the failure of the proletariat to achieve a subjective consciousness of their objective misery, the Frankfurt School (particularly Horkheimer in his earlier work) reevaluated the intellectual's role in catalyzing the proletariat. The first suggestion of how a new revolutionary class would emerge had the intellectual acting not autonomously but in a dynamic unity with the proletariat. The intellectual would supply the theoretical basis for a revivified consciousness of the proletariat, and the proletariat in turn would supply the mass base for acting out their theoretical vision in practice.

The earliest formulations of Horkheimer bound the intellectual inextricably to the proletariat. It was not until the 1950's and 1960's, perhaps because of the radically increased reification of the general consciousness, that the Frankfurt School (most particularly Marcuse) identified a new revolutionary subject, more or less independently of the proletariat. Benjamin, who died in 1940, never abandoned his hope for the proletariat; to him the proletariat always remained the revolutionary agent, in some ways far more so than for the rest of the Frankfurt School. Adorno and Horkheimer, even after their estimate of the authentic revolutionary potential of the proletariat had become deeply pessimistic, rarely considered explicit historical alternatives to the proletariat. In a way, their great hope was in the proletarian and the failure of the proletariat left them with little beyond despair. In the end, even while they were caught up in the student and radical upsurge of the 1960's, they tended to distance themselves carefully. It was Marcuse who affirmed the need for an historically exogenous revolutionary force and embraced the student and Third World movements as the great historical alternatives to the proletariat.

10. Karl Klare has explained the fundamental premise of CLS in the following passage, which cites articles by a number of Critical scholars:

The ways we think about social problems shape our conceptions of what is historically possible, our images of freedom and justice. A growing body of literature argues that legal thought is an important constitutive component of the modern American political imagination. Legal discourse often serves to legitimate the pre- 
If one parent of Critical legal scholarship is the Critical Theory of European Marxist sociology, the other parent is the American Legal Realism of 50 years ago, with its insight that formalistic legal reasoning inevitably conceals subjective value choices. Legal Realism rejects the notion of legal "autonomy," i.e., that there is a method of legal reasoning that can generate outcomes in controversial disputes independent of the political or economic ideology of the judge. The cast of mind that results when these two schools of thought are united has been summarized by John Henry Schlegel:

Many of the legal scholars currently at work on a Critical jurisprudence, including the two published here [Al Katz and Duncan Kennedy], share a belief that law is relative to social practice and social theory; that contemporary jurisprudence is an obfuscating apologetic; that legal analysis that gets relevant by gesturing outside law toward a pseudo-consensus morality or the technical abstraction of efficiency has already lost its own battle for autonomy and is madly searching for allies who have seemingly secured their own autonomous turf; that there can be no plausible legal theory without a social theory; and that the notion of legal autonomy is a lie. ${ }^{11}$

The quotation is from the introduction to the issue of the Buffalo Law Review that contains Duncan Kennedy's article on "unpacking" Blackstone's Commentaries. ${ }^{12}$ In the introductory part of his article, which has been extremely influential within the CLS movement, ${ }^{13}$ Kennedy expresses a Critical perspective at the level of individual psychology. According to Kennedy, there is a "fundamental contradiction" in our relations with other people: We both need them and fear them. We need to "experience fusion" with others even to form

vailing social order. It can induce us to believe that existing arrangements and institutions are rational and just, or at least inevitable, and thereby inhibit us from perceiving the contingency of present arrangements and institutions or the ways in which they are maintained by human choice and coercive force. Legal discourse as legitimating ideology is therefore itself a form of political domination and a barrier to progressive change. In turn, radical criticism of traditional legal discourse might help to create needed intellectual space and to nurture the ideas and images of freedom that must inform any movement for social change.

Klare, The Quest for Industrial Democracy and the Siruggle Against Racism: Perspectives from Labor Law ana' Civil Rights Law, 61 OR. L. REv. 157, 162 (1982) (footnotes omitted).

11. Schlegel, Introduction, 28 Buffalo L. ReV. 203, 203 (1979).

12. Kennedy, The Structure of Blackstone's Commentaries, 28 Buffalo L. REv. 205 (1979).

13. Crucial paragraphs from this article have been cited, quoted, and discussed at length in other CLS articles. See, e.g., Brest, The Fundamental Rights Controversy, 90 Yale L.J. 1063, 1108 (1981); Frug, The City as a Legal Concept; 93 HaRv. L. Rev. 1057, 1152-54 (1980); Kelman, Misunderstanding Social Life: A Critique of the Core Premises of "Law and Economics", $33 \mathrm{~J}$. LEGAL EDUC. 274, 281 (1983). Kennedy's influence in general is acknowledged in many CLS articles. 
our own personalities, but we fear that others will try to dominate us, to deny our freedom and individuality. And so they do: "Through our existence as members of collectives, we impose on others and have imposed on us hierarchical structures of power, welfare, and access to enlightenment that are illegitimate, whether based on birth into a particular social class or on the accident of genetic endowment."14

Kennedy holds out no easy hopes for escape from this predicament. In fact, in two remarkable paragraphs, he describes the situation as practically hopeless:

The kicker is that the abolition of these illegitimate structures, the fashioning of an unalienated collective existence, appears to imply such a massive increase of collective control over our lives that it would defeat its purpose. Only collective force seems capable of destroying the attitudes and institutions that collective force has itself imposed. Coercion of the individual by the group appears to be inextricably bound up with the liberation of that same individual. If one accepts that collective norms weigh so heavily in favor of the status quo that purely "voluntary" movement is inconceivable, then the only alternative is the assumption of responsibility for the totalitarian domination of other peoples' minds-for "forcing them to be free."

Even this understates the difficulty. It is not just that the world of others is intractable. The very structures against which we rebel are necessarily within us as well as outside of us. We are implicated in what we would transform, and it in us. This Critical insight is not compatible with that sense of the purity of one's intention which seems often to have animated the enterprise of remaking the social world. None of this renders political practice impossible, or even problematic: We can identify oppression without having overcome the fundamental contradiction, and do something against it. But it does mean proceeding on the basis of faith and hope in humanity, without the assurances of reason. ${ }^{15}$

But, even to proceed on that slender thread of hope, we need to recognize our situation. Kennedy suggests that the fundamental contradiction may always have existed, in which case we "need to account for the obvious fact that it has either not been experienced at all, or not acknowledged, by any of the succeeding generations of Western legal thinkers between the time of the sophists and the very

14. Kennedy, supra note 12 , at 212 . I am using lengthy, verbatim quotes from CLS articles throughout this essay so readers can be certain that I am not distorting anyone's message or attacking a straw man of my own creation. I invite readers to compare my method with that of CLS authors, particularly William Simon, when they refer to this article or to other writing which is critical of CLS.

15. Id. at 212-13. 
recent past."16 The explanation for our failure to have perceived the contradiction lies in the continual existence of "processes of mediation, or denial, that have functioned to hide or disguise it from those engaged in the enterprise of legal thought."17 Eventually one of these modes of mediation-liberalism-became dominant. In Kennedy's words, liberalism masks reality by "splitting . . . the universe of others into two radically opposed imaginary entities," private civil society and the state. "In civil society, others are available for good fusion as private individual respecters of rights; through the state, they are available for good fusion as participants in the collective experience of enforcing rights. A person who lives the liberal mode can effectively deny the fundamental contradiction." 18

The task of Critical legal thought is to pierce through accepted intellectual categories to the reality of the fundamental contradiction that lies behind them. As our thinking becomes more sophisticated, we will understand that every legal issue can be reduced to "a single dilemma of the degree of collective as opposed to individual self-determination that is appropriate." 19 But what will happen when this feat is accomplished? Are we capable of resolving the fundamental contradiction once we face it squarely? Here again are Kennedy's words:

It is true that the categories of individual and collective, and freedom and power, represent an insuperable contradiction within our experience. But it is also true that we embrace, generalize and intensify the contradiction by accepting it uncritically as part of the nature of things. To some extent, we are the victims of our own reification rather than of our historical circumstances. To this extent "thinking makes it so." The task of criticism is to demystify our thinking by confronting us with the fact that the contradiction is a historical artifact. It is no more immortal than is the society that created and sustains it. Understanding this is not salvation, but it is a help. ${ }^{2 \sigma}$

Kennedy's article follows a general pattern that is typical of Critical legal scholarship. A fundamental social fact is announced: Our relations with other people are ambivalent and complex (this is the "fundamental contradiction"), or life in capitalist society is alienating, ${ }^{21}$ or legal economics cannot solve our problems without reference

16. Id. at 213 (emphasis in original).

17. Id. at 213-14.

18. Id. at 217.

19. Id. at 213 .

20. Id. at 221 (emphasis in original).

21. According to Peter Gabel, liberal legal philosophers "confuse a historically contin- 
to a substantive theory of justice, ${ }^{22}$ or workers and management do not have "equal" power in collective bargaining, ${ }^{23}$ or our political life is characterized more by class conflict and oppression than by shared values and consensus. ${ }^{24}$ The particular social condition identified should be obvious, but most people do not comprehend it because of an ideological blindness or false consciousness. Gritical legal scholarship usually identifies liberalism or "liberal legalism" as the blinding ideology. ${ }^{25}$ Liberalism in this context does not refer to the political program of the left wing of the Democratic party in the United States. ${ }^{26}$ The Critical scholars are themselves, after all, crea-

gent social experience with human nature, reifying 'man' in their own alienated self-image and constructing imaginary 'communities' which are simply idealized representations of the alienated social relationships they have known in their own lives." Gabel, Book Review, 91 HARV. L. REV. 302, 311-12 (1977).

22. See Heller, The Importance of Normative Decisionmaking. The Limitations of Legal Economics as a Basis for a Liberal Jurisprudence-As Illustrated by the Regulation of Vacation Home Development, 1976 WIS. L. REV. 385.

23. See Klare, Judicial Deradicalization of the Wagner Act and the Origins of Modem Legal Consciousness, 62 MinN. L. Rev. 265 (1978); Stone, The Post-War Paradigm in American Labor Law, 90 YALE L.J. 1509 (1981).

24. See Tushnet, Truth, Justice, and the American Way: An Interpretation of Public Law Schalarship in the Seventies, 57 TEx. L. REv. 1307, 1307-08 (1979) (citing O. W. Holmes to support the argument that the commonality of interest presumed by liberal theory cannot exist in a class-divided society); see also Kelman, Interpretive Construction in the Substantive Criminal Law, 33 STAN. L. REV. 591, 646 (1981) (conventions of blameworthiness in criminal law reflect perspective of "the people administering our criminal justice systems, who know they will never - . . face the pressures of a truly bleak social background.").

25. Karl Klare has given a helpful definition of "liberal legalism" as the Critical legal scholars understand it:

Liberal legalist jurisprudence is closely related to the classical liberal political tradition. The metaphysical underpinnings of the enumerated practices are supplied by the central philosophical themes of that tradition: the notion that values are subjective and derive from personal desire, and that therefore ethical discourse is conducted profitably only in instrumental terms; the view that society is an artificial aggregation of autonomous individuals; the separation in political philosophy between public and private interests (between state and civil society); and a commitment to a formal or procedural rather than a substantive conception of justice.

KJare, supra note 23, at 276 n.36 (citing Morton Horwitz, Roberto Unger, and Duncan Kennedy).

26. At least one of the political programs commonly termed "liberal" in the United States-protection of the natural environment for its own sake-is difficult to justify on the basis of liberal political theory. See, e.g., Tribe, Ways Not to Think About Plastic Trees: New Foundations for Environmental Law, 83 YALE L.J. 1315 (1974). On the other hand, free market "conservatives" sometimes claim that they are the true or "19th century" liberals. In the United States, "liberal" and "conservative" are often used as synonyms for "left" and "right" with sometimes hilarious results. The wife of a Nixon administration cabinet member once described antiwar demonstrators as "very liberal communists," and reporters occasionally describe Nazis as "extremely conservative."

By using the term "liberal rationalism," I hope to make clear that we are considering a kind of intellectual framework rather than a particular political agenda. Free market or lib- 
tures of the left. Rather, the liberalism that the Critical scholars attack is a school of political philosophy that originated with Hobbes, Locke, and Hume.

Liberal political theory in this sense assumes that society is composed of autonomous individuals whose values are based upon subjective desires. It aims not to transform those values but to accommodate them through institutions like the free market, majority rule, collective bargaining, the social contract, and the United States Constitution. ${ }^{27}$ It assumes that a society made up of such individuals has common values, or at least can agree on procedures to resolve value conflicts when they do exist.

Although they grant that liberals are often sincere in their pursuit of justice, ${ }^{28}$ the Critical legal scholars believe that the liberal approach tends to rationalize oppression rather than to cure it. This is because liberals underestimate the degree of social conflict and the extent to which the privileged classes can manipulate "neutral" governmental processes to their own advantage. Liberals also make an arbitrary distinction between public and private compulsion, which fosters an illusion that people are free when government is restricted. $^{29}$ Once the smoke-screen of liberalism has been lifted, we

ertarian theorists like Milton Friedman, Robert Nozick, and Richard Posner are definitely included, because they argue from liberal premises. These thinkers are not "conservative"" in the sense that Edmund Burke and Samuel Johnson were conservative.

27. Alan Freeman describes the shared value approach in the following manner:

Most legal scholarship rests on the presupposition that there exists a community with a harmony of interest sufficient to give rise to identifiable shared values . . . .

The shared value approach permits the commentator to establish principles or concepts-for example, representative democracy, economic efficiency, reasonable expectations, equal concern and respect-against which to test the validity of particular doctrines or decisions and find some of them wanting, while applauding the convergence of others with the identified underlying value.

Freeman, Truth and Mystification in Legal Scholarship, 90 YALE L.J. 1229, 1233-34 (1981). Freeman, a member of the CLS movement, denies the existence of this harmony of interest. See id. at 1236 .

28. See, e.g., Kennedy, supra note 12, at 210.

29. See Abel, A Socialist Approach To Risk, 41 MD. L. Rev. 695, 718 (1982) ("Autonomy is not ensured by eliminating political restraints. That is the great myth of liberalism. Economic, social, and psychological constraints are just as important and often more powerful."); see also Klare, supra note 10, at 161 ("[T] he public/private distinction-2.e., the belief that it is possible to conceive of the realm of social and economic intercourse as being fundamentally distinct and separated from the realm of government and public policy-is basic to the ideological justification via the substance/process distinction of class hierarchy and racial domination."). For a perceptive comment on this point of view, see Mnookin, The Public/Private Dichotomy: Political Disagreement and Academic Repudiation, 130 U. PA. L. REV. 1429 (1982).

To the extent that it genuinely rejects any distinction between public and private activity, the CLS movement is literally "totalitarian." 
will recognize the underlying oppression and alienation inherent in modern society, and then we will become able to conceive of new forms of human association that do not involve domination and hierarchy. To that end, Critical articles demystify some area of liberal or conventional legal doctrine by demonstrating its contradictory or arbitrary assumptions, sometimes contributing provocative insights that can be appreciated whether or not one accepts the Critical approach.

However, whether any radical or utopian conclusions follow from a successful demystification is questionable. The political implications of Critical legal scholarship depend upon the cause of the underlying oppression or alienation, not its mere existence. The ambivalence on this crucial point, which is typical of Critical scholarship, is well illustrated by the portions of Duncan Kennedy's article on Blackstone's Commentaries quoted above. ${ }^{30}$ Is the "fundamental contradiction" an inevitable element of the human condition, an artifact of a particular kind of society, or an illusion that will vanish if we change our individual ways of thinking? It will not do to say only that it is "to some extent" all of these things because we have to decide whether societal change, personal change, or fatalistic acceptance is the most promising way to deal with it. If the cause of oppression is even partly within us, or if oppression is inherent in human relationships, why isn't a political solution at least "problematic"? The point is all the more puzzling because what Kennedy calls a "contradiction" is not a logical contradiction at all but merely a reflection of the complexity of human relationships. Children love their parents but resent parental supervision, adults desire the security of marriage but chafe at its restrictions, and citizens regard the police both as protectors and oppressors. What conceivable political change could alter all this, assuming that it ought to be altered?

A similar uncertainty about the cause of our ills is reflected in the uneasy relationship between Critical legal scholarship and Marxism. Some of the articles from the CLS movement are explicitly Marxist, and the movement as a whole employs Marxist jargon and methods of analysis. Marxist remedies, however, are rarely recommended. Although they do not dwell upon the point, the Critical scholars seem to be aware of the consistently horrible record of Marxist regimes $^{31}$ - the slave labor camps, the mass deportations, the suppres-

30. See notes 12-20 supra and accompanying text.

31. There are occasional vague references to the dangers of Stalinism or "the social catastrophes of the twentieth century." Kennedy, Cost-Reduction Theory as Legitimation, 90 
sion of labor unions, the denial of freedom of conscience, the bureaucratic rigidity, the personality cults. They appear to recognize that refugee traffic between Marxist and non-Marxist societies is a one-way affair.

Understandably, even radical scholars in a sophisticated intellectual community hesitate to embrace such an inviting target for "Critical" scrutiny by others. This ambivalence can lead to amusing equivocations. The prolific Mark Tushnet, for example, pays Marxism the compliment of saying that it "generates the central position to which all theories of knowledge respond,"32 and he has tried his hand at sketching a Marxist analysis of American public law. ${ }^{33}$ But we must not assume that Tushnet is therefore a Marxist, for he has also written that he "uses Marxism" merely as a "rhetorical mode" to show that he realizes that those in positions of power will not peacefully relinquish those positions when the time comes, and to demonstrate that he is a real radical and not just another reformer like John Hart Ely or Lawrence Tribe. ${ }^{34}$ How a rhetorical mode can generate a central position to which all theories must respond is not explained.

What Tushnet and other Critical legal scholars seem to like about Marxism is its doctrine of historical contingency, its insistence that "all knowledge is a social product and thus that knowledge can have no transcendent validity." 35 This "Critical" side of Marxism is useful for attacking "capitalism" or "liberalism" (although it could be equally useful in undermining Marxism itself), ${ }^{36}$ and as such it can

YALE L.J. 1275, 1283 (1981); Tushnet, Legal Scholarship: Its Causes and Cure, 90 YALE L.J. 1205. $1215 \mathrm{n} .39$ (1981). References to Stalin or "Stalinism" in this context may be meant to imply that the reign of Stalin was a singular exception to the otherwise benign record of Marxist administration.

32. Tushnet, supra note 31 , at 1220 .

33. See generally Tushnet, supra note 24.

34. See Tushnet, Deviant Science in Constitutional Law, 59 TEx. L. REx. 815. 826 (1981). Tushnet also hints at other, unspecified reasons for his "use" of Marxism.

Tushnet sheds further darkness on his relation to Marxism in a review of a book titled Marxism and Law. A Marxist analysis of law is probably impossible, he suggests, because it would have to rest on "problematic epistemological assumptions." Nonetheless, Marxism has value because in one sense it "is the only remaining secular view that is committed to fighting domination wherever it occurs." Tushnet, Book Review, 68 CoRnell L. Rev. 281, 290 (1983). Possibly his intent here is ironical, but Tushnet seems to be confusing Marxism with anarchism.

35. Tushnet, supra note 31 , at 1220 .

36. For a genuinely "Critical" analysis of Marxism, which relates it to the social conditions that made its categories seem plausible, see A. ULAM, THE UNFINISHED REvOLUTION (rev. ed. 1979). Of course, Marxism is extremely useful to totalitarian propagandists, who can invoke devices like the theory of false consciousness to persuade people to ignore their own common sense. 
be detached from the Marxist program of party dictatorship. Marxism as a practical revolutionary program is attractive mainly to those who, like Dostoyevsky's Grand Inquisitor, ${ }^{37}$ believe that the important thing is to feed the hungry and that human liberty is worth sacrificing to that end. The Critical scholars are well aware that man does not live by bread alone. Their primary concern is for social equality, for abolition of hierarchies of power. ${ }^{38}$ Marxist dictatorship is no solution to that problem.

But discarding the vulnerable positive program of Marxism generates at least two further difficulties, neither of which has been adequately addressed in any of the Critical legal literature with which I am familiar. First, how are we to judge the validity of a Marxist critique of capitalist society if Marxism is so wrong in its positive program? There is an analogy here to the predicament of psychoanalytic theory now that the efficacy of psychoanalysis as a form of treatment has been strongly called into question. ${ }^{39}$ Conceivably the Freudian theories of the personality might be true even if treatment based on those theories has no special power to cure, but the power to cure has always been an important argument for the truth of the theory. ${ }^{40}$ The failure of Marxism as a remedy for exploitation and oppression is so spectacular as to call into question its central doc-

37. F. Dostoyev'sky; The Brothers Karamazov 303-24 (C. Garnett trans. 1929).

38. Critical legal scholarship also reflects the Frankfurt School's loathing for "bourgeois philistinism." See note 8 supra. For a flavor of the kind of dissatisfaction that causes the Critical scholars to demand radical change, see Freeman, supra note 27, at 1230 (disgust for "abstract, rightsy, traditional bourgeois notions of justice"); Gabel, supra note 21, at 311-12 (revulsion at "the mechanical functioning that most people call work, the packaged emptiness of fast food, the obsessive manipulation of appliances that occupies the boredom of leisure time, and the sort of 'love' that attempts to realize desire through ambivalent dependency and pornographic fantasy"); Kennedy, supra note 31, at 1275-76 (bleakness of life in New Haven, Connecticut).

39. The effectiveness of psychoanalysis in curing mental disease has never been established by controlled studies. Research on the effectiveness of psychotherapy has tended to show a modest effect when compared with untreated control groups. There is no evidence that orthodox Freudian psychoanalysis is more effective than far less costly therapies. Research is reported in Epstein \& Vlok, Research on the Results of Psychotheraty: A Summany of Evidence, 138 AM. J. Psychiatry 1027 (1981); Luborsky, Singer \& Luborsky, Comparative Studies of Psychotherapies, 32 ARchives Gen. Psychiatry 995 (1975).

40. Freud often substantiated his theories with claims of therapeutic success, as when he described the importance of free association and dream analysis in the treatment of phobias:

If we can induce [the patient] to abandon his criticism of the ideas that occur to him, and to continue pursuing the trains of thought which will emerge so long as he keeps his attention turned upon them, we find ourselves in possession of a quantity of psychical material, which we soon find is clearly connected with the pathological idea which was our starting-point; this material will soon reveal connections between the pathological idea and other ideas, and will eventually enable us to replace 
trines, including the premise that economic or political institutions are to blame for our psychological and spiritual ills. How are we to verify or falsify a Marxist or Marxist-style analysis? Critical legal scholarship seems to rule the question out of order. We are entitled to be suspicious, especially since Critical Theory appeals so powerfully to the egotism of disaffected intellectuals like the CCLS members by granting them special insight and a pivotal role in history. ${ }^{41}$

The second major problem with a purely negative use of Marxism is that criticism itself is meaningless without a standard of reference, whether express or implied. Critical scholars who describe "capitalist" society as oppressive or hierarchical are like New Yorkers who speak of Cleveland as being in the "West." Contemporary capitalist society may be oppressive and hierarchical judged by some ideal standard and yet have less oppression and hierarchy than most or even all other societies that have ever existed. Critical legal writing systematically evades the question, "Compared to what?"

My point is not that one always has to propose an alternative

the pathological idea by a new one which fits into the nexus of thought in an intelligible fashion.

This is not the place in which to give a detailed account of the premises upon which this experiment was based, or the consequences which follow from its invariable success. It will therefore be enough to say that we obtain material that enables us to resalve any pathological idea if we turn our attention precisely to those associations which are "involuntary," which "interfere with our reflection," and which are normally dismissed by our Critical faculty as worthless rubbish.

S. Freud, On Dreams, in 5 The Complete Psychological Works of Sigmund Freud 636 U. Strachey ed. 1958) (emphasis added).

41. Karl Popper made a similar point in satirizing Karl Mannheim's "sociology of knowledge," a type of Critical theory:

For just like the psychoanalysts, the people to whom psychoanalysis applies best, the socioanalysts with almost irresistible hospitality invite the application of their own methods to themselves. For is not their description of an intelligentsia which is only loosely anchored in tradition a very neat description of their own social group? And is it not also clear that, assuming the theory of total ideologies to be correct, it would be part of every total ideology to believe that one's own group was free from bias, and was indeed that body of the elect which alone was capable of objectivity? Is it not, therefore, to be expected, always assuming the truth of this theory, that those who hold it will unconsciously deceive themselves by producing an amendment to the theory in order to establish the objectivity of their own views? Can we, then, take seriously their claim that by their sociological self-analysis they have reached a higher degree of objectivity; and their claim that socioanalysis can cast out a total ideology? But we could even ask whether the whole theory is not simply the expression of the class interest of this particular group; of an intelligentsia only loosely anchored in tradition, though just firmly enough to speak Hegelian as their mother tongue.

K. Popper, The Open SOciety AND ITs ENemies 402 (1950) (footnote omitted). 
when one criticizes, but rather that failure to specify the standard of reference robs the criticism of meaning. When Critical scholars say that life in a capitalist society is alienating, I do not know if they mean that this is true because of some particular characteristic of capitalist society or because life in every known form of society is alienating. If the latter is the case, then blaming alienation on capitalism is absurd.

In a word, the relationship of Critical legal thought to Marxism or any other ideological position is obscure. Without a firm ideological basis the Critical viewpoint is itself obscure, and indeed it is not easy to explain how Critical scholarship differs from "liberal" or "traditional" scholarship, except in its greater obscurity. ${ }^{42}$ Liberal scholarship itself is strongly Critical, and may even have prepared the way for nihilism by undermining so much that had seemed certain.

Perhaps the difference between Critical legal scholarship and standard liberal legal scholarship can best be captured by describing the former as aiming at a more consistent skepticism, as calling into question not merely particular solutions or propositions but the enterprise of rationalistic analysis itself. Paul Brest's article on the "fundamental rights controversy" in constitutional law ${ }^{43}$ provides a good example, and the subject is probably familiar enough to most readers that no extensive description is necessary. Unlike practically everyone else who has contributed to the debate about how to reconcile the antimajoritarian institution of judicial review with the principle of majority rule that is supposedly central to our constitutional democracy, Brest proposes no solution. On the contrary, he declares the "Madisonian dilemma"- the inherent clash between majority rule and minority rights - to be unresolvable on any theory that legal scholarship can advance. ${ }^{44}$ Strict interpretivism is ruled out by the existence of open-ended clauses in the Constitution itself, consensus or natural law theories are easily exposed as incorporating controversial subjective preferences, and "process" theories like that of John Hart Ely fail to avoid the need to invoke substantive standards to

42. "[E]ven when my critique is clearest, it is infuriatingly difficult to distinguish from the more sophisticated and cynical forms of liberalism." Kennedy, First Year Law Teaching as Political Attion, 1 LAW \& SOC. ProBs. 47, 54 (1980). Exactly so. The only way to escape the liberal paradigm is to offer a plausible alternative. Without that, mere skepticism, however extreme, is easily accommodated by the liberal world view. David Hume. a consummate skeptic, was one of the founders of liberalism.

43. Brest, The Fundamental Rights Controversy: The Essential Contradictions of Normative Constiutional Scholarship, 90 YALE L.J. 1063 (1981).

44. See id. at 1105. 
judge whether the majoritarian political process is working correctly. ${ }^{45}$

Brest's article differs from a good liberal article on the same subject only in that he flatly refuses to offer a "lesser evil" solution for the problem he has described as insoluble. Instead, he indulges in a sentence or two of utopian fantasy, suggesting that a "genuine reconstitution of society" 46 might somehow make the Madisonian dilemma go away. This refusal to address the pragmatic issue-What is the Supreme Court to do, given that there are valid objections to any course of action?-is typical of Critical legal scholarship, and explains why this kind of writing is so unsatisfying to persons of a practical bent. If the Critical scholars are making the point that utopian fantasy is the only alternative to conventional legal thought, then they are making the strongest possible pragmatic argument for maintaining our conventions.

Regrettably, few articles from the CLS movement are as well written or well argued as the work of Paul Brest. The main purpose of Critical legal scholarship is to debunk traditional legal scholarship, and there are plenty of inviting, debunkable targets. The problem is that most of the Critical scholars are not good debunkers, mainly because of the ideological baggage they have to carry, specifically Marxism. It is well known that Marxists take a dim view of everything that is done in "capitalist" (i.e., non-Marxist) societies. To a Marxist the capitalist system is responsible for every form of misery in the world-unemployment, wage slavery, pollution, war, imperialism, the subjugation of women, and so on. The abuses of capitalism reflect its inherent tendencies, and superficial reforms are undertaken merely to stave off revolution and maintain the hegemony of the ruling class. The Marxist point of view is something that one assumes rather than proves, and any piece of evidence can be made to fit it. Thus, CLS articles have argued that collective bargaining legitimates employer domination of the workplace, ${ }^{47}$ that antidiscrimination laws legitimate institutional racism, ${ }^{48}$ and that Ronald Dworkin wrote Taking Rights Seriously in order to legitimate contemporary advanced capitalism. ${ }^{49}$ All this is probably true if

45. See id. at 1090-95.

46. Id. at 1109 .

47. See Klare, supra note 23; Stone, supra note 23.

48. See Freeman, Legitimizang Racial Discrimination Through Antidiscrimination Law: A Critical Revieu' of Supreme Court Doctrine, 62 MinN. L. REv. 1049 (1978); Freeman, Book Review, 90 YALE L.J. 1880, 1893-94 (1981)

49. See Gabel, supra note 21. 
Marxism is true, but to non-Marxists it isn't convincing, especially when it comes from people who themselves admit to having doubts about Marxism.

Mark Kelman's ambitious attempt to debunk the entire field of substantive criminal law ${ }^{50}$ distracts the rea der by mixing an intellectual attack on the logical coherence of criminal law doctrine and scholarship with some implausible Marxist-style explanations of their ideological purposes. For example, scholars who protest strict liability crimes which punish the "blameless" are portrayed as "raising hysterically excessive defenses" against determinist claims that everybody is blameless; ${ }^{51}$ commentators who protest the criminalization of victimless or consensual acts are helping "to certify the wage-work and buyer-seller dealings as nonexploitative and harmonious ...."52 It is not clear whether Kelman is being serious or merely playful in suggesting these possibilities. In the concluding section of his article, he discusses three distinct possible interpretations of his enterprise, concluding that perhaps "the interpretive constructs I note are not politically meaningful at all, but simply inexplicably unpatterned mediators of experience, the inevitably non-rational filters we need to be able to perceive or talk at all."${ }^{\text {.53 }}$

50. See Kelman, supra note 24 .

51. Id. at 610 .

52. Id. at 615-16. The celebrated flexibility of Marxist analysis may be illustrated by comparing Mark Tushnet's analysis of the same issue: Conservatives resist legalizing prostitution-and drug use because they fear that such changes may subtly undermine the legitimacy of private property. See Tushnet, Sex, Drugs, and Rock 'n Roll: Some Conservative Refections on Liberal Jurisprudence (Book Review), 82 CoLUM. L. REV. 1531, 1542-43 (1982).

53. Kelman, supra note 24, at 671 . Kelman's article is an example of "deconstruction" or "trashing." Kelman's general thesis is one with which I enthusiastically concur: There is a great deal of bad reasoning in criminal law, both in the judicial opinions and in the scholarly commentary. Unfortunately, there is still more of it since Professor Kelman entered the field. To begin with, the target of his attack is poorly defined. Why pick as the prime example of "standard doctrinal argument" a dissenting opinion by Judge Skelly Wright, a judicial maverick? And does Kelman think he is the first to have observed that the distinction between voluntary and involuntary conduct is elusive? Compare Kelman, supra note 24, at 600-03, with Powell v. Texas, 392 U.S. 514 (1968). Kelman slashes through the field of criminal law, discussing holdings, opinions, scholarly criticism, obscure common law doctrines, and whatever else suits his purpose; makes a series of debunking arguments of the kind we criminal law teachers routinely bring up in class; and then concludes that criminal law is incoherent and irrational. If this is deconstruction, what is the text?

Kelman repeatedly flagellates whomever it is he is attacking for failing to confront the implications of a "full-blown determinism." See, e.g., id. at 663 . I would agree that, for instance, the Model Penal Code's insanity defense is an unsatisfactory cornpromise between intentionalist and determinist philosophy. Kelman's discussion is seriously misleading, however, because he mistakenly assumes that whenever the law recognizes excusing conditions (e.g., duress, infancy, or provocation), it is partially accepting determinism. This is by no means necessarily true. Intentionalists (believers in free will) do not believe that all choices 
But why go to such trouble to insinuate devious political purposes and then be so unconcerned with whether they are real or imaginary?

The irony is that nothing is more vulnerable to a Marxist critique than the CLS movement itself. Most of these scholars are law professors at prestigious universities, predominantly at Harvard and Stanford; such a career implies acceptance by the legal intellectual establishment. From this platform they preach a sort of nihilistic utopianism, a most unconvincing doctrine that in no way threatens the existing order of society. Their visibility at the elite universities lends credibility to the image of neutrality and tolerance that the Ruling Hegemony wishes to project. Their rhetoric reassures law students that the only alternatives to the present system are "utopian." The obvious Marxist explanation of the CLS movement is that it permits a few harmless academic leftists to adopt a radical pose, while receiving good salaries and excellent fringe benefits for serving the interests of the capitalists. ${ }^{54}$

are equally culpable, nor do they deny that people are sometimes under strong pressure to act one way rather than another. One who is threatened with death if he does not provide confidential information, for example, can choose to submit or die. Even if we consider the choice to be voluntary, we may excuse the chooser because we do not demand extreme self-sacrifice from ordinary people. This is not determinism, partial or otherwise.

In any case, it is self-contradictory to criticize a legal system for failing to respond adequately to arguments based on a "full-blown determinism." If individual human acts are determined, then a social product like the criminal law is a fortion determined, and criticism of it is as pointless as blaming criminals. Like those he criticizes, Kelman accepts determinism when it suits him and discards it when he wants to blame somebody. In this respect he is a true follower of Marx himself, who constantly berated the capitalists for fulfilling their assigned historical role.

Of course the doctrine of free will has its problems, as does determinism, of the hard or soft variety. Anyone with something new to contribute to this ancient debate is welcome to join in. Very likely the criminal law approaches the problem of free will with a series of intuitions rather than a consistent intellectual doctrine. What better do you have to suggest, Professor Kelman?

54. Consider the nonscholarly publications of Professor Duncan Kennedy of Harvard in this connection, especially his Rebeis from Principle: Changing the Corporate Law Fim from Vithin, 33 HARv. L. SCH. Bull. 36 (fall 1981). This piece urges leftist Harvard Law School graduates to subvert their law firms from within by being "subtle, collusive, skillful, and tricky." By behaving this way, they "should be able to do left office politics without being fired, and make partner." Id. at 40 . Could this be a coded warning to Harvard alumni to beware of hiring law associates whose leftist views may inspire disloyalty? What honest conspirator broadcasts his strategy to the enemy?

On a more serious note, this exhortation to young corporate lawyers to "resist illegitimate hierarchy and alienation" in their law firms, id. at 38, strikes me as ambivalent. Read one way, it seems to be urging young lawyers to betray their clients and employers with all sorts of dishonest schemes to advance "left" causes. Read another way, it is urging them only to retain a sense of decency and public service, and not to use client or employer pressure as a general "cop-out" for abandoning their own ethical standards. The piece left me with the 
A better explanation would avoid all insinuations of conspiracy or hypocrisy and point out merely that the present period is an extremely difficult one for political utopians who are at all intellectually honest. There are many people in academic life who sincerely want to be radical; they want to use their intelligence to plan a better world, and they feel contempt for the insensitive "bourgeois mentality" that rules business and government. For such people, Marxism has a practically irresistible attraction: By attributing everything that is unsatisfactory about life to particular economic or political arrangements, Marxism offers a possibility that revolutionary political change can bring about personal and corporate salvation. Marxist regimes can be disowned and Marxist proposals can be abandoned, but what is indispensable about Marxism for the utopian leftist is its explanation of evil. Abandon that, and politics becomes a pragmatic attempt to mitigate the inevitable defects in human nature. Social criticism from a utopian viewpoint then becomes pointless.

But the history of Marxism in practice, and even the history of conflict and adventurism within American leftist groups, makes faith in the Marxist diagnosis exceedingly difficult to sustain. I believe that the notorious murkiness of Critical legal scholarship and its occasional frivolity 55 tend to "mediate" or "mystify" a lack of conviction on this crucial point. This explanation may also help account for the failure of the Critical scholars to propose alternatives to the liberal institutions for which they have so little respect.

The question of alternatives is an important one which $I$ intend to explore in Part III of this essay. Before that, however, I wish to take a look at liberal rationalism (my preferred term for what the Critical legal scholars call "liberalism," or "liberal legalism") to see what it is that the Critical legal scholars are so Critical about. I believe that the skepticism Critical scholarship expresses about the possibility of legalistic or "procedural" solutions to problems of social conflict is to some extent justified, that the CLS movement has identified a genuine problem however far wrong it goes after that. There are a few grains of wheat in this mountain of chaff after all.

overall impression that Kennedy does not consider ethics or decency to be something distinct from leftist political activity.

55. See, e.g., Freeman, supra note 27 (glorifying "trashing" as a scholarly activity); Kennedy, supra note 31; Tushnet, supra note 34 , at $826 \mathrm{n.42}$; see also note 54 supra. 


\section{Liberal Rationalism and Sham NeUtrality}

For purposes of this analysis legal reasoning may be roughly divided into two schools of thought: the "positivist" and the "natural justice" 56 traditions. A positivist views law as the command of a sovereign, a body of rules that exists apart from any notion of justice derived from some other source. Positive law is discovered by reading statutes or cases with the assistance of conventional interpretive techniques. Law determined in this manner should be rational to the extent that the legislator is presumed to be rational, but it need not coincide with the morals or sense of justice of judges or scholars.

The competing natural justice tradition presupposes a relationship between law and principles of justice derived from religion, philosophy, science, or nature. To a judge of this school, a statute or decision that violates natural justice is no law at all. Techniques of interpreting statutes, cases, and constitutional language are expected to produce results consistent with the judge's vision of natural justice.

The two approaches are not necessarily incompatible. For example, one may be able plausibly to assert that the legislator or constitution-maker endorsed natural justice principles in some way. ${ }^{57}$ If so, interpreting the legislation or constitutional provision to make it conform to those principles can be justified under a positivist theory even if the interpretation does some violence to the language. On the other hand, no theory of natural justice is so systematic and detailed as to provide an answer to every question. A judge who is determined to decide for the right and against the wrong regardless of the cold letter of the positive law will nonetheless consult positive law on a large number of issues where his sense of right and wrong does not dictate an answer. The positivist judge will likewise be aware that positive law does not answer every question, and that equally legitimate canons of interpretation may lead to different answers. Natural justice principles or intuitive values may legitimately guide the positivist judge where the trail of positive law gives out.

When I entered law school a generation ago, the judges I was taught to admire were those like Cardozo and Traynor who were thought to be capable of combining the positivist and natural justice approaches. By "creative" legal reasoning, a great judge could "interpret" the relevant legal materials to make them consistent with his

56. I am using the term "natural justice" to avoid confusion with the specific Aristotelian-Thomistic doctrine of natural law.

57. Constitutional law activists frequently assert that the "open-ended" clauses of the United States Constitution implicitly incorporate an expansive concept of inherent rights. 
own sense of fairness or good social policy. ${ }^{58}$ This was not to be done every day, of course; but, on important occasions when much was at stake and the time ripe for change, the great judge could ensure that the law responded to social needs. Such judicial law reform was not seen as a partisan activity because it was assumed that intelligent and learned people would have similar views about what direction reform ought to take.

When a generation of lawyers has learned to emulate the great judges, however, perceptions of what is going on necessarily change. Creative opinion-writing is practiced ever more frequently by lesser craftsmen, and the skeptical audience becomes ever more expert at recognizing the manipulative techniques that give the judge leeway to be creative. Courts begin to acknowledge more or less openly that they are changing the law rather than merely interpreting it from a fresh perspective. The very practice of reforming law by judicial decision sparks demands for more of the same. ${ }^{59}$ Once a high court has discarded some "arbitrary" limitation on the right to recover damages for negligently inflicted emotional harm, for example, it impliedly invites counsel to argue that other "arbitrary" limitations on recovery should be eliminated as well. Gradually, every limitation begins to seem arbitrary because there is no "natural" line dividing damages that are recoverable from those that are not. ${ }^{60}$

Thereafter, decisions that follow the tradition require justification just as much as decisions that depart from it. Justifying a decision as required by precedent is unpersuasive when one has demonstrated an ability to distinguish or even disregard an inconvenient precedent when one really wants to do so. The same point can also be made with regard to constitutional or statutory language. Who can sympathize with a Supreme Court Justice who voted with the majority to

58. See, e.g., G. Christie, Jurisprudence: Text and Readings on the Philosophy OF LAw 980-81 (1973). Christie describes two aspects of Karl Llewellyn's jurisprudence-his endorsement of the "Grand Style" of common law decisionmaking and his emphasis on "Situation-Sense." By thorough understanding of, say, commercial practices, the great judge would develop a feel for the desirable result or rule. The "Grand Style" enabled him to "discover" or to implant this solution in the law without creating an appearance of arbitrariness. This style "is a way of on-going renovation of doctrine, but touch with the past is too close, the mood is too craft-conscious, the need for the clean line is too great, for the renovation to smell of revolution, or indeed, of campaigning reform." Id. at 980 (quoting $\mathrm{K}$. LLEwELLYN, THE COMMON LAW TRADITION 36 (1960)). I cannot imagine anyone describing the judicial opinions of today as examples of the "Grand Style."

59. See J. Ely, Democracy and Distrust 48 (1980).

60. See, e.g., Molien v. Kaiser Found. Hosps., 27 Cal. 3d 916, 616 P.2d 813, 167 Cal. Rptr. 831 (1980) (illustrating difficulty of restricting actions for recovery of damages for emotional distress once "arbitrary" limitations have been abandoned). 
create a constitutional right to abortion in Roe $v$. Wade ${ }^{61}$ when he claims that the Constitution "ties his hands" on some other issue like the death penalty?62 If the Constitution can fairly be read to incorporate the liberal morality of today in one case, then why not in the other as well? The activist judge who invokes precedent or statutory compulsion on a convenient occasion is no more believable than the prostitute who pleads chastity as an excuse for rejecting a customer.

The natural justice approach thus tends to swallow the positivist approach once it is understood that the latter is supposed to be the servant of the former. This situation poses no problem as long as judges agree about the content of natural justice, but consensus is inevitably threatened once judges get the idea that "the law" need not be independent of their personal values. As long as law is conceived as an autonomous set of positive rules that the judge simply applies, Critical attention naturally focuses on those particular rules that offend practically everyone's sense of natural justice. At this stage, concepts of "shared values," "community standards," or "conventional morality" seem plausible as fixed reference points from which to criticize inherited legal doctrines. But when the issue shifts from, say, the legality of "Jim Crow" discrimination to the legality of preferences for blacks in medical school admissions, ${ }^{63}$ latent contradictions in the community's moral standards come to the surface. Eventually, all the disagreements that characterize partisan politics can reappear in the courtroom as rival interpretations of law.

When matters have reached this stage, judges face an intimidating array of conflicting value judgments and even conflicting views of reality. Some people want a sexually permissive society; others want their children to grow up in "decent" surroundings. Some people think that liberty includes a right to belong to exclusive clubs or to live in exclusive communities; others think that equality demands a systematic societal prohibition of "discrimination." Some people be-

61. 410 U.S. 113 (1973).

62. See Furman v. Georgia, 408 U.S. 238, 405-14 (1972) (Blackmun, J., dissenting). Mr. Justice Blackmun, the author of the majority opinion in Roe v. Wade, expressed his personal opposition to capital punishment and his conviction that it "serves no useful purpose that can be demonstrated." Furman, 408 U.S. at 405 . He felt nonetheless that capital punishment was constitutional because Supreme Court justices "should not allow [their] personal preferences as to the wisdom of legislative and congressional action, or [their] distaste for such action, to guide [their] judicial decision in cases such as these." Id. at 411 .

63. The rich vocabulary of affirmative action disputes_-"reverse discrimination," "institutional racism," "goals and timetables," "quotas," and "race-conscious remedies for past discrimination"-indicates how unhelpful the "shared value of racial equality" is in resolving such controversies. 
lieve that business enterprises should be permitted to grow and combine to increase efficiency; others see big business as the natural enemy of the little man and hope to see it cut down to size whenever the opportunity arises. Some people want to redistribute the costs of accidents and other misfortunes through an expansive tort liability system or compulsory social insurance; others think individuals should be expected to take care of themselves. Some people want women to have a protected role in society so they can concentrate on home and family; others want to free women to compete on equal terms with men. Some people want to protect fetal life; others want free abortions as an officially approved form of birth control. Some people think that criminals are to blame for their crimes; others place the blame on social or environmental circumstances for which "society" is ultimately responsible.

Up to a point we can reason about these conflicts and even hope to change each other's minds, for the disagreements turn to some extent on matters of fact and experience. But when all reasoning and argument are over, there will be reasonable and well-informed people on both sides of each controversy. How is the deadlock to be resolved? One answer is through a political process that supposedly represents the will of a majority of voters. The standard objection to unchecked majority rule, of course, is that minority rights deserve to be protected from majority tyranny. But even if we were to accept the verdict of a national majority on all questions that it actually decides, an extensive judicial lawmaking power would still be necessary because the Congress can only decide a limited number of issues and because the actions of state legislatures would still have to be reviewed by some national authority. As we all have come to recognize, a vast increase in judicial power has come about not only because judges want to assume power but also because a complex pluralistic society generates an enormous number of controversial issues and because legislators survive by trying to be all things to all men. ${ }^{64}$ The legislative art is increasingly one of reaching agreement on essential matters like the budget by papering over the great issues of principle that threaten to fragment the community. The effect of these compromises is usually to leave the real decisions to the executive branch and, eventually, to the judiciary.

But what principles or values should guide the judges as they make the decisions that shape society? It is sufficient justification for a legislative judgment that it reflects the legislators' notion of their

64. This situation is described, and deplored, in J. ELY, supra note 59, at 131-34. 
constituents' best interests, but judges have to claim to be guided by something more objective than their personal beliefs. For this reason, the stalemate in the "fundamental rights controversy" in constitutional law ${ }^{65}$ illustrates a problem that permeates every aspect of judicial decisionmaking, and not merely judicial review of legislative judgments. The courts need to refer to values not only in constitutional cases, but also when they are construing "ambiguous" legislation, or when they are making common law in areas like tort and contract. Should the presumption be for freedom of contract or consumer protection, for individual responsibility or societal risk-spreading, for respecting traditional definitions of sex roles or challenging them, for fostering economic growth or protecting the environment, for traditional morality or individual choice? When judges determine "the law" in cases dealing with these sorts of issues, do they really do anything very different from what congressmen do?

The judiciary has an enormous stake in an affirmative answer to that question, because its power depends heavily on the public's willingness to believe that the courts arrive at doctrines through some process of objective reasoning. If the public ever came to believe in Legal Realism, the independence of the judiciary would be in danger. A mystique is needed to prevent this calamity. We see this mystique at work when activist judges pretend that all they do is to carry out the intent of the Framers of our Constitution, when elite law school professors and bar association leaders unite to discourage Congress from passing legislation that challenges Supreme Court rulings, and when legislators are criticized for grilling nominees for judicial office about their substantive views instead of sticking to their "qualifications."

I am not saying that this piety is entirely unjustified. The electoral process has its own techniques of mystification, and perhaps universal candor would make civilization impossible. Furthermore, there may be no realistic alternative to a broad judicial lawmaking power, however it is exercised. My purpose here is not to urge the judges to change their ways but to draw attention to the extraordinary seriousness with which most academic lawyers take the process of judicial rationalization. Mark Tushnet's description of the typical constitutional law article is classic:

The typical constitutional law article today has a standard form. The author identifies a doctrine developed in recent Supreme Court cases, notes some difficulties in the internal logic of

65. See text accompanying notes $43-46$ supra. 
the doctrine, indicates that the doctrine seems incompatible with the results of other cases, suggests minor modifications in the doctrine to make it consistent with those cases, and concludes that the doctrine as modified-almost uniformly into a balancing test-provides a sensible way of achieving results without going too far. As we will see, there are some variations on this form; for example, authors can adapt it to a vigorous rejection of Supreme Court decisions. But the standard form and its variants all end at the same place: Supreme Court decisions ordinarily are, and in any event can easily become, embodiments of principles of justice, defined as the standard political principles of the moderate left of the Democratic Party. In the end, the balancing tests . . reintroduce the very flexibility that allows courts to disagree with those principles. $^{66}$

Student notes in the elite law journals on politicized subjects like constitutional and criminal law frequently advocate some left-liberal position with a formalistic rhetorical style that would better suit an article on the history of the rule against perpetuities. Their transparent intention is to sell a partisan view disguised as something else. But mature writers who are both less tendentious and more sophisticated also seem to write as if ideological conflicts were a sort of puzzle to which legal reasoning can provide the right answer. This assumption-that there are neutral reasoning techniques that can generate solutions that transcend ideological conflicts-is what I mean by liberal rationalism. ${ }^{67}$ The trouble is that the "neutral" reasoning succeeds only because it proceeds from a definition of the issue that covertly resolves the ideological conflict.

Let me illustrate my point with a blatant but not atypical example. The abortion cases present a clear example of what would seem to be inescapable value conflict: Is abortion akin to homicide, or is it a morally neutral alternative to childbirth? But when the California Supreme Court held that the right to privacy enshrined in the state constitution forbids excluding abortion from Medicaid benefits, it denied that any moral issues were present.

At the outset, to dispel certain misconceptions that have appeared in this case, we must clarify the precise, narrow legal issue before this court. First, this case does not turn on the morality or

66. Tushnet, supra note 24 , at $1322-23$.

67. I must emphasize that liberal rationalism is not political liberalism, as we ordinarily use the latter term in the United States. What is "liberal" about this rationalism is not its political program but its purported neutrality about individual ends and its consequent bias towards procedural conceptions of justice. See note 25 supra and accompanying text. At least one of liberal rationalism's procedural devices-the free market-is customarily identified with "conservative" politics. 
immorality of abortion, and most decidedly does not concern the personal views of the individual justices as to the wisdom of the legislation itself or the ethical considerations involved in a woman's individual decision whether or not to bear a child. Indeed, although in this instance the Legislature has adopted restrictions which discriminate against women who choose to have an abortion, similar constitutional issues would arise if the Legislature-as a population control measure, for example-funded Medi-Cal abortions but refused to provide comparable medical care for poor women who choose childbirth. Thus, the constitutional question before us does not involve a weighing of the value of abortion as against childbirth, but instead concerns the protection of either procreative choice from discriminatory governmental treatment. ${ }^{68}$

Of course, we can describe abortion and childbirth as equivalent "procreative choices" only after we have weighed "the value of abortion as against childbirth." To say that two things are morally equivalent (e.g., property is theft, or socialism is slavery) is to make a moral judgment, sometimes a strong one. The quoted passage is a particularly brazen example of what I call "sham neutrality." The basic technique is to affect an above-the-battle "neutral" pose of sheer reasonableness, while smuggling the resolution of the value conflict into the definition of the issue. The sham may be conscious, unconscious, or something in between; the mind has a way of failing to see what it doesn't want to see.

The Supreme Court's famous opinion in Brown v. Board of Educa$t^{t i o n}{ }^{69}$ may be used to illustrate that controversial decisions, even "liberal activist" ones, do not necessarily employ sham neutrality. The key step in the Court's reasoning was the "finding" that racially segregated schools are inherently unequal because they impose a label of inferiority upon the black children. In a sense, the decision in Brown reflected not so much a new reading of the Constitution as a new understanding of the effect and purpose of racial segregation. Herbert Wechsler cited Brown as a decision that did not rest on "neutral principles,"70 and he argued that a "neutral" (i.e., utilitarian) way to characterize the issue would be to treat it as a (probably unresolvable) conflict between the preferences of those who like interracial association and those who do not. ${ }^{71} \mathrm{I}$ admire the opinion for the very absence of "neutral" legal reasoning that Wechsler deplored. The constitutionality of "separate but equal" schooling turned upon

68. Committee to Defend Reproductive Rights v. Myers, 29 Cal. 3d 252, 256. 625 P.2d 779, 780, 772 Cal. Rptr. 866, 867 (1981) (majority opinion by Tobriner, J.).

69. 347 U.S. 483 (1954).

70. Wechsler, Toward Neutral Principles of Constitutional Law, 73 HARV. L. REV. 1 (1959).

71. Id. at 34 . 
whether one characterized it as a reasonable accommodation of differing preferences, or as one of the devices by which white people kept black people in a condition of subordination. A good judicial opinion (or scholarly article), in my view, is one that identifies such Gritical characterization issues candidly and resolves them forthrightly, without seeking to bury the decisive step under a camouflage of neutral rationalization. ${ }^{72}$

I have chosen my examples expressly to illustrate my point, and of course a single example or even a group of examples proves nothing about legal reasoning or legal scholarship in general. I will not attempt to prove the point in this brief essay, but it is my opinion that sham neutrality is characteristic of even some of the better legal writing of our time. The problem is not bad reasoning, but reasoning that has to proceed from inadequate premises to avoid seeming to endorse any controversial ideological position. In other words, the necessity for sham neutrality as a decisionmaking technique stems from the liberal pose of ideological neutrality.

The current impasse of liberal moral philosophy illustrates the same problem. James Fitzjames Stephens once imagined the law telling a pimp that society would give no weight to his opinion in deciding the appropriate punishment for pimping. ${ }^{73}$ Liberal

72. Many controversial constitutional questions boil down to issues of social fact or characterization. See, e.g., Powell v. Texas, 392 U.S. 514 (1968) ("Should we erect a constitutional doctrine on speculation about determinism?" versus "Should we ignore the teaching of medical science that public intoxication is a symptom of the disease of alcoholism?"); Mapp v. Ohio, 367 U.S. 643 (1961) ("Should the criminal go free because the constable blundered?" versus "Should the courts refuse to acquiesce in pervasive police contempt for fourth amendment rights?'). Obviously the Constitution itself does not tell us whether psychiatric opinion is scientific or speculative, or whether the police are on the whole mindful of the fourth amendment or contemptuous of it. This is not to say that if the empirical questions could be answered no doctrinal differences would exist.

73. In this famous passage, Stephen ridiculed John Stuart Mill's hesitation as to whether society may suppress occupations like pimping, in which a profit is earned by persuading others to engage in vice. Mill implied that solicitations to vice might be discouraged only where they are not "disinterested." Stephen responded:

I do not think the State ought to stand bandying compliment with pimps. 'Without offence to your better judgment, dear sir, and without presuming to set up my opinion against yours, I beg to observe that I am entitled for certain purposes to treat the question whether your views of life are right as one which admits of two opinions. I am far from expressing absolute condemnation of an experiment in living from which I dissent (I am sure that mere dissent will not offend a person of your liberality of sentiment), but still I am compelled to observe that you are not altogether unbiassed [sic] by personal considerations in the choice of the course of life which you have adopted (no doubt for reasons which appear to you satisfactory, though they do not convince me). I venture, accordingly, though with the greatest deference, to call upon you not to exercise your profession; at least I am not indisposed to 
philosophers find it difficult to make this sort of statement because the happiness of the pimp is entitled to just as much weight on the utilitarian's scales as that of anyone else and because it is debatable whether pimping and prostitution "harm" other people. ${ }^{74}$ On the other hand, many people will be extremely unhappy if pimping and prostitution are not punished. Whether the total amount of unhappiness will be greater if pimping and prostitution are permitted or punished is unascertainable and, in any case, the utilitarian calculus is irrelevant if one side or the other has a "right" to prevail.

It is common today to reject utilitarianism because it fails to "take seriously the distinction between persons,"75 or because in some sense it fails to "treat persons as equals." I I believe that neither of these objections expresses the real problem, which is that the utilitarian posture of neutrality towards competing desires or preferences is inevitably a sham. Nobody really balances the pleasure of the rapist against the agony of the victim to decide whether to prohibit rape. Neither philosophy nor law can get along without some standard for distinguishing "legitimate" or "preferred" desires from others. It is because utilitarianism cannot provide such a standard that legal philosophy has had to turn from utility to "rights" as its central concept.

think that I may, upon full consideration, feel myself compelled to do so.' My feeling is that if society gets its grip on the collar of such a fellow it should say to him, 'You dirty rascal, it may be a question whether you should be suffered to remain in your native filth untouched, or whether my opinion about you should be printed by the lash on your bare back. That question will be determined without the smallest reference to your wishes or feelings; but as to the nature of my opinion about you, there can be no question at all.'

J. Stephen, LiberTy, Equality, Fraternity 137-38 (White ed. 1967).

74. Ronald Dworkin has noted the vagueness of the concept of "harm" as a guide to deciding whether to suppress pornography:

Everything turns on what 'harm' is taken to be. If 'harm' includes only direct physical damage to particular people, or direct damage to their property or financial interests, then the condition is much too strong, since it would condemn a large part of standing British and American law. It would forbid regulating the commercial development of certain parts of cities, or restricting the private use of natural resources like the sea shore. Almost everyone would reject the harm condition interpreted in that way. But if 'harm' is broadened to include mental distress or annoyance, then the condition becomes much too weak to be of any use in political theory, since any kind of conduct likely to be made criminal in democracy, at least, is conduct that causes annoyance or distress to someone. Suppose 'harm' is taken to exclude mental distress, but to include damage to the general social and cultural environment. Then the harm condition is in itself no help in considering the problem of pornography, because opponents of pornography argue, with some force. that free traffic in obscenity does damage the general cultural environment.

Dworkin, Is There a Right to Pomography?, 1 OxFORd J. Leg.Al STud. 177, 178 (1981).

75. J. RaWLS, A Theory OF JUSTICE 27 (1971).

76. R. DWORKIN, TAKING RIGHTS SERIOUSLY 231-38 (1977). 
But a shift in language solves nothing in itself. We can talk of rights instead of higher and lower pleasures or whatever, but how do we know that these rights are founded upon anything more substantial than arbitrary desires? Contemporary "neo-Kantian" moral philosophy has made an ambitious attempt to answer this question, but the answers have not stood up well to critical analysis. John Rawls' device of imagining a hypothetical social contract in an "original position"77 has a certain appeal to the liberal imagination, but careful readers of Rawls are aware that the original position is more a metaphor than an argument. The particular contract that emerges depends upon the knowledge and character traits that the contractors are deemed to have, and these in turn reflect one's intuitions about what the contractors ought to choose. ${ }^{78}$ Ronald Dworkin's effort to derive a theory of rights by combining utilitarianism with a distinction between "personal" and "external" preferences has been devastatingly criticized by H. L. A. Hart, ${ }^{79}$ and Dworkin himself seems ready to give it up. ${ }^{80}$ Dworkin's achievement is considerable, but

77. J. Rawls, supra note 75 passim.

78. Rawls' seminal work has provoked an avalanche of thoughtful criticism that collectively undermines his theory at numerous points. Some of the most powerful refutations are contained in B. ACKerman, SOCIAL Justice in the Liberal State 320-42 (1980); B. Barry, The Liberal Theory of Jlistice (1973); R. Nozick, ANarchy, STATE, and UtoPIA 183-224 (1974); M. SANDEL, Liberalism AND THE Limits OF JUSTICE (1982); R. WOlfF, UNDERSTANDING RAWLS (1977). I do not mean to question the value or importance of Rawls' work. If he has lost the argument, it is only after raising it to a higher level.

79. Hart, Between Utility and Rights, 79 Colum. L. REv. 828, 836-46 (1979).

80. As Dworkin himself has stated:

My aim is to develop a theory of rights that is relative to the other elements of a political theory, and to explore how far that theory might be constructed from the exceedingly abstract (but far from empty) idea that government must treat people as equals. Of course that theory makes rights relative in only one way. I am anxious to show how rights fit into different packages, so that I want to see, for example, which rights should be accepted as trumps over utility if utility is accepted, as many people think it should be accepted, as the proper background justification. That is an important question because, as I said, at least an informal kind of utilitarianism has for some time been accepted in practical politics. It has supplied, for example, the working justification of most of the constraints on our liberty through law that we accept as proper. But it does not follow from this investigation that I must endorse (as I am sometimes said to endorse) the package of utilitarianism together with the rights that utilitarianism requires as the best package that can be constructed. In fact I do not. Though rights are relative to packages, one package might still be chosen over others as better, and I doubt that in the end any package based on any familiar form of utilitarianism will turn out to be best. Nor does it follow from my argument that there are no rights that any defensible package must contain-no rights that are in this sense natural rights-though the argument that there are such rights, and the explanation of what these are, must obviously proceed in a rather different way from the route $I$ followed in arguing for the right to moral independence as a trump over utilitarian justifications. 
what he has shown is that utilitarianism without a theory of rights is incoherent, not that the existence of rights can be demonstrated. ${ }^{81}$

Moral philosophy is a fascinating enterprise, but it has considerable trouble with its starting point. The problem is not the quality of the philosophers; liberal moral philosophers such as Rawls, Dworkin, and Nozick are capable of brilliant leaps, but they lack a firm place to plant their feet. What each thinker comes out with depends upon the starting point that he arbitrarily chooses.

The enormous importance of equality in contemporary liberal thinking is a manifestation of how difficult it is to get started. Equality is the value that looks as if if weren't a value, that can be made to seem the "neutral" starting place when values are absent. For example, a liberal egalitarian theory may begin with the observation that inequalities of wealth or status are not deserved because all our talents are the product of genetic or environmental "luck."82 Putting it that way makes equality of wealth seem like an appealing intuitive starting.point for a theory of economic justice, although inequalities

Dworkin, supra note 74 , at $210-11$.

Dworkin 's current work appears to aim at deriving a political theory directly from the concept of equality See Dworkin, Why Liberals Should Beliete in Equality, N.Y. Rev. Books. Feb. 3, 1983. at 32; Dworkin, What Liberalism Isn't, N.Y. Rev'. Books. Jan. 20, 1983, at 47; Dworkin, What Is Equality? (pts. 1 \& 2), 10 PHIL. \& PuiB. AfF. 185, 283 (1981).

81. Alasdair Maclntyre has made this point with characteristic pungency:

The best reason for asserting so bluntly that there are no such rights is indeed of precisely the same type as the best reason which we possess for asserting that there are no witches and the best reason which we possess for asserting that there are no unicorns: every attempt to give good reasons for believing that there are such rights has failed. The eighteenth-century philosophical defenders of natural rights sometimes suggest that the assertions which state that men possess them are self-evident truths; but we know that there are no self-evident truths. Twentieth-century moral philosophers have sometimes appealed to their and our intuitions; but one of the things that we ought to have learned from the history of moral philosophy is that the introduction of the word "intuition" by a moral philosopher is always a signal that something has gone badly wrong with an argument. In the United Nations declaration on human rights of 1949 what has since become the normal U.N. practice of not giving good reasons for any assertions whatsoever is followed with great rigor. And the latest defender of such rights, Ronald Dworkin (Taking Rights Senous $(y, 1976$ ) concedes that the existence of such rights cannot be demonstrated, but remarks on this point simply that it does not follow from the fact that a statement cannot be demonstrated that it is not true (p. 81 ). Which is true, but could equally be used to defend claims about unicorns and witches.

A. MACINTIRE. AFTER VIRTUE 67 (1981) (emphasis in original). This type of argument must be employed with caution, however. If there are no self-evident truths, then there is no self-evident way to allocate the burden of proof, either.

82. See J. RawLS, supra note 75, at 73-74; see also B. ACKERMAN, supra note 78, at 129-38; Dworkin, What is Equalty? -Part 2: Equality of Resources, 10 PHIL. \& PeB. ArF. 283, 314 (1981). 
may be tolerated if they result from incentive structures that benefit the disadvantaged by increasing societal wealth. From this point on, the game is to derive increasingly specific and controversial policy choices from the platitudinous but purportedly uncontroversial starting point of equality.

But it is equally plausible to start with liberty as our basic value, and to place a heavy burden of persuasion on those who want to use the inherently clumsy authority of the state to substitute an "artificial" equality for the inequality characteristic of the natural order. From this point of view "equality" as a moral imperative is a delusion, a quixotic ideal that can never do more than substitute one form of inequality for another. ${ }^{83}$ And yet to glorify inequality because it is a fact of life is no more satisfactory than to condemn it because it is a fact of life. Undoubtedly the natural order sets limits on what kinds of society we can achieve, but it does not tell us whether we ought to be celebrating the natural inequality of talents or counteracting it. No doubt we actually rely on our "moral intuitions" for such judgments because we have no alternative. But the appeal to intuition is not intellectually reassuring either. Our intuitions often conflict, and in any case they may be the product of social conditioning or genetic inheritance, and thus part of the existing order whose legitimacy is in question.

Besides equality, the value most closely associated with liberal rationalism is tolerance, meaning open-mindedness and respect (not necessarily equal respect) for the other person's point of view. Most of us would agree that this is an excellent value indeed, especially if the alternative is violent strife between conflicting religious or secular

83. The best brief statement of this vewpoint I have encountered is by the British economist P. T. Bauer:

Why, in free and open societies such as those of Western countries, are some people better off than others-not necessarily wiser, nicer, happier or more virtuous, but bettcr off? The precise causes of differences in income and wealth are complex and various, and people will always disagree on how they apply to particular societies, groups or individuals. But in substance such differences result from people's widely differing aptitudes and motivations, and also to some extent from chance circumstances. Some people are gifted, hard-working, ambitious, and enterprising, or had far-sighted parents, and they are therefore more likely to become well-off.

In an open and free society, political action which deliberately aimed to minimize, or even remove, economic differences (i.e. differences in income and wcalth) would entail such extensive coercion that the society would cease to be open and free. The successful pursuit of the unholy grail of economic equality would exchange the promised reduction or removal of differences in incorne and wealth for much greater actual inequality of power between rulers and subjects. There is an underlying contradiction in egalitarianism in open societies.

P. Bauer, Equaltty, the Third WORld, and Economic Delusion 8 (1981). 
ideologies. But attractive as it is, tolerance cannot be the only value or the supreme value in a legal order. Law exists because it is necessary to set limits on what society will tolerate, and simplistic concepts like "causing harm to others" conceal a multitude of controversial choices. ${ }^{84}$

Like equality, tolerance is a substantive value that may seem to be derived from relativism itself: If no opinion is absolutely right, shouldn't we respect all opinions equally? The error is in failing to see that tolerance itself is a value, and one that has to be limited in some way lest it degenerate into permissiveness. We may aim to combat "antidemocratic" or "destructive" attitudes with education rather than with police and jails, but we still have to know what to combat. Any social order is, and ought to be, concerned with forming public values, and not merely with passing laws to govern behavior. ${ }^{85}$ One reason we maintain a huge public educational system is its supposed effectiveness in promoting those values that society has determined to be "good." Enormous efforts have been made in recent years to ensure that the textbooks used in public schools portray racial minorities in a favorable light, and show women in professional roles rather than in predominantly domestic roles as wives and mothers. Schools in previous generations stressed other values, including personal honesty, respect for authority, and self-reliance. While the content of public morality has changed over time, particularly in emphasis, Realists have consistently recognized that laws are ineffective unless the citizens internalize the values that underlie them.

Value relativism supports liberalism at one level, because it undercuts any claim to absolute or divine preference for any one value system. The corresponding problem is that it undercuts any such claim for "liberal" values as well. That is why the value choices have to be hidden, why liberal rationalism must always seem to be invoking only reason, or values like "liberty," "equality," or "tolerance," that seem to be uncontroversial because they are so vague. The struggle to establish which values will predominate is to liberal rationalism what sex was to the Victorians: We know that it has to go on, but decent people don't talk about it in public. Fortunately, ideological conflict is not as bitter in our society as in many others, a

84. See note 74 supra; see also Kaplan, The Role of the Law in Drug Control, 1971 Duke L.J. 1065 (analyzing various types of "harm" that may justify prohibiting or regulating a selfdestructive activity).

85. A persuasive argument on this point is made in J. TUSSMAN, GOVERNMENT AND THE MIND (1977). 
circumstance I would credit mainly to widespread prosperity and our common religious heritage.

Nothing I have said necessarily detracts from the argument for liberal neutrality as a rhetorical mode or practical strategy. It may be better to make our value judgments in an unconscious or concealed manner than to confront them head on. Possibly bringing the value conflicts into the open, and acknowledging that we do not know how to solve them, would have disastrous consequences. Fear of such consequences might reasonably lead some who think they see through the false pretenses of liberal rationalism to pretend to believe in it anyway, in the manner of agnostics who send their children to Sunday School. Some might even try to will themselves to believe, to assert the existence of common values or an objectively ascertainable public morality as a matter of faith, relying on the power of thundering rhetoric to intimidate the doubters. ${ }^{86}$ This sort of reaction is common and understandable when the foundations of one's world view are under attack and the only alternative seems to be anarchy.

But I think the stability of our present legal order depends less on its intellectual coherence than on the political astuteness that our most powerful judges bring to their task. For all the rhetoric about absolute rights and principled decisionmaking, acute ideological conflicts on subjects like affirmative action, abortion, public aid to religious schools, and rights of criminal suspects are usually accommodated by statesman-like compromises that seem unprincipled from any theoretical perspective. ${ }^{87}$ Pragmatic accommodation

86. Owen Fiss provides an example in one of his recent essays:

Against the nihilism that scoffs at the idea that the Constitution has any meaning, it is difficult to reason. The issue seems to be one of faith, intuition, or maybe just insight. This form of nihilism seems so thoroughly at odds with the most elemental reading of the text itself and with almost 200 years of constitutional history as to lead me to wonder whether anything can be said in response. On the other hand, I believe is imperative to respond, in word and in deed, for this nihilism calls into question the very point of constitutional adjudication; it threatens our social existence and the nature of public life as we know it in America; and it demeans ours lives. It is the deepest and darkest of all nihilisms. It must be combatted and can be, though perhaps only by affirming the truth of that which is being deniedthe idea that the Constitution embodies a public morality and that a public life founded on that morality can be rich and inspiring.

Fiss, Objectivity and Interpretation, 34 STAN. L. Rev. 739, 763 (1982).

87. Thus, racial minorities may have preference in medical school admissions provided a quota is not too blatantly advertised, women have a constitutional right to abortion but the government may exclude abortions from medical benefits, religious schools may receive public aid in some forms but not others, and we allow plea bargaining but exclude confessions obtained by threats or promises. Alasdair MacIntyre has stated the point realistically:

Liberal writers such as Ronald Dworkin invite us to see the Supreme Court's func- 
is the true art of government in the judicial as well as in the legislative and executive branches: Abstract theories about rights or utilities or defects in the majoritarian process may be advanced sincerely, but they are only one factor in making the law.

In taking this "Realist" position that legal theory both mystifies and legitimates judicial power, I find myself at one with the Critical legal scholars. Yet this is odd. I had thought that Legal Realism was currently a conservative position, because it tends to discredit left-liberal judicial activism. The electoral political process tends on the whole to be dominated by middle class and traditional values; the judicial political process has been much more open to the leftist values of the intellectuals, who claim authority to speak for the poor and the deprived. ${ }^{88}$ Presumably, the Critical scholars do not attack the ideology of the intelligentsia in order to aid their class enemy, the bourgeoisie. What, then, is their purpose?

tion as that of invoking a set of consistent principles, most and perhaps all of them of moral import, in the light of which particular laws and particular decisions are to be evaluated. Those who hold such a view are bound to consider certain decisions of the Supreme Court inadequate in the light of these supposed principles. The type of decision which I have in mind is exemplified by the Bakke case, where two, at first sight strongly incompatible, views were held by members of the [C]ourt, and $\mathrm{Mr}$. Justice Powell who wrote the decision was the one justice to hold both views. But, if my argument is correct, one function of the Supreme Court must be to keep the peace between rival social groups adhering to rival and incompatible principles of justice by displaying a fairness which consists in even-handedness in its adjudications. So the Supreme Court in Bakke both forbade precise ethnic quotas for admission to colleges and universities but allowed discrimination in favor of previously deprived minority groups. Try to conjure up a set of consistent principles behind such a decision and ingenuity may or may not allow you to find the court not guilty of formal inconsistency. But even to make such an attempt is to miss the point. The Supreme Court in Bakke, as on occasion in other cases, played the role of a peacemaking or truce-keeping body by negotiating its way through an impasse of conflict, not by invoking our shared moral first principles. For our society as a whole has none.

A. MACINTYRE. supro note 81 , at 235-36.

I agree with MacIntyre's point, but the final sentence is overstated. Our society does have widely shared moral principles, but they are too general to decide the controversy over affirmative action. In addition, much of the apparent disagreement over principles disguises a more important, but suppressed, controversy over the social facts. Very few people are happy about the historic shortage of black medical doctors, or about the inability of a sufficient number of blacks to gain admission to medical school on the ordinary criteria. What is controversial is how one accounts for the situation and how one goes about curing it.

88. Paul Brest's observation that judges are "mostly white, male, professional, and relatively wealthy," Brest, supra note 4 , at 771 , is true but misleading. The legal elite is a group in which one finds enthusiastic support for feminism and affirmative action, as anyone who teaches at a prestigious law school cannot help but be aware. 


\section{The Problem of Solutions}

There is no mystery about what the Critical legal scholars are against: They are against capitalism, liberalism, and illegitimate hierarchy. It is much harder to say what they are for. In fact, Critical legal writing has practically nothing to siggest in the way of a positive political program. For a movement that claims to be political, this is truly an astonishing vacuum. At the 1981 Yale Symposium on Legal Scholarship, for example, Duncan Kennedy called for "utopian speculation," "dreaming up the ways we think things might be better than they are," because radicals need to ask, "What would we do with power, anyway?"89 On the same occasion, Alan Freeman chided his colleagues for failing to follow through on the radical implications of their papers. The most he could propose himself, however, was that radicals should escape from liberal thinking by incorporating "insights from other methods: structuralism, phenomenology, advanced Marxist thought, radical empiricism, and comparative methods." $" 90$ Roberto Mangabeira Unger concluded his book Law in Modern Society by observing that the solution to the conflict between personal autonomy and community "could be fully worked out only with the help of a metaphysics we do not yet possess." Whatever may have been their authors' intentions, the polit-

89. Kennedy, supra note 31 , at 1283 . On the same page Kennedy also urged his student audience to "hassle, harass, demonstrate and sit in" against the Yale Law School faculty to force it to hire more women and blacks. I suppose this qualifies as a positive program, although my impression is that CCLS is as white-male-dominated as the Yale Law School faculty.

90. Freeman, supra note 27, at 1237 (footnotes omitted). This research agenda is proposed, mind you, for a movement whose primary mission is to demystify law.

91. R. UNGER, LAW IN MODERN SOCIETY 261, 266-68 (1976). Unger is very much a special case, and generalizations about the CLS movement do not necessarily apply to his work. His intelligence and learning are extremely impressive, but it is difficult to know what to make of his (so far) inconclusive writing. See Leff, Memorandum, 29 STAN. L. REV. 879 (1977) (reviewing R.UNGER, KNOWLEDGE AND Polrtics (1975)). It will be interesting to see if his next book moves in the direction of greater clarity or greater obscurity about what, if anything, he is advocating.

I received Unger's The Critical Legal Studies Movement, 96 HARv. L. REv. 561 (1983), after this article was completed. Unger's latest writing is an extremely dense, 115-page statement of his personal vision for the movement. It appears to state a positive program for radical legal theorists, although it does so at such an abstract level that Unger can plausibly disown any interpretation of his writing that threatens to become embarrassing. The heart of Unger's social vision is a "cultural-revolutionary practice" aimed at "the systematic remaking of all direct personal connections-like those between superiors and subordinates or between men and women-through their progressive emancipation from a background plan of social division and hicrarchy." Id. at 587. The individual "should not be the puppet of his place in the contrast of classes, sexes, and nations," id. at 584; rather, "the cultural-revolutionary program . . . wants the opportunities and experiences available to different categories of people 
ical implications of these messages seem conservative to me. If we not only don't know how to get there from here, but also don't know where "there" is, doesn't it follow that we should stay here until more information comes along?

Positive proposals from the CLS movement never go far beyond a general endorsement of equality, participatory democracy, and (sometimes) socialism. The Critical labor law commentators want to replace the present system of collective bargaining over wages, hours, and working conditions with worker control of industry, so that the workplace can become "a realm of free self-activity and expression."92 Paul Brest hopes to reconstitute society around a concept of freedom that "includes citizen participation in the community's public discourse and responsibility to shape its values and structure."93 Richard Parker plans to "take seriously and work from (while, no doubt revising) the classical conception of a republic, including its elements of relative equality, mobilization of the citizenry, and civic virtue." P4 Peter Gabel more grandly imagines "a living milieu in

to be more freely recombined." Id. at 587 . This freeing of the individual from the tyranny of sex, class, nationality, and hierarchy is to be undertaken by the state, making use of an extensive category of "destabilization rights": "The central idea of the system of destabilization rights is to provide a claim upon governmental power obliging government to disrupt those forms of division and hierarchy that, contrary to the spirit of the constitution, manage to achieve stability only by distancing themselves from the transformative conflicts that might disturb them." Id. at 612 .

Apparently the family, the churches, and both public and private educational institutions would be prime targets of Professor Unger's cultural revolution. If this interpretation is correct, I can no longer describe his work as "inconclusive," to say the least. Set out in the pages of the Harvard Law Review, it all sounds antiseptic and intellectual: There is no hint that police and mob terror will inevitably be the agents of transformation. How else can all direct personal connections be remade, and all existing forms of division and hierarchy be disrupted? The cultural revolution is no tea party, even when the invitations come on Harvard stationery.

92. Klare, supra note 23, at 339; see also Stone, supra note 23, at 1580 (advocating "true industrial democracy" where "the wage contract is . . . a concern of society as a whole").

Special mention should be made here of Richard Abel's $A$ Socialist Approach to Rusk, 41 MD. L. REv. 695 (1982). This article contradicts itself with a disarming nonchalance. Everyone should have "autonomous control over his own risk," but he may not exercise this control in a "false or unsocialized" way. The notion that a person "might wish autonomously to increase his own risk beyond that experienced by others" is "largely a figment of the imagination of bourgeois economists." Nonetheless, "people voluntarily incur numerous risks, many of them extreme, in their recreational pastimes." It is "important to preserve the freedom to engage in such activities." But because such "self-destructive behavior" may adversely affect "families, friends, [and] social units that feel an obligation to care for the ill or injured," they "have the right to try to persuade the participant not to incur the risk and perhaps even to curtail his or her ability to do so." Id. at 718. All this on a single page!

93. Brest, supra note 13 , at 1109 (footnote omitted).

94. Parker, supra note 2, at 258 n.146. Presumably, the glorification of war and con- 
which human labor is a creative social activity, in which the production of material goods is purposely designed to satisfy real human needs, and in which each person recognizes the other as 'one-of-us' instead of 'other-than-me' irrespective of sex or skin color."95 If Mark Tushnet were appointed to the Supreme Court, he would use his power to promote "socialism."

In short, the CLS program is platitudinous. Racial and sexual equality, civic virtue, meaningful work, satisfaction of "real human needs," active citizen participation in public affairs-these could be the least controversial planks in the platform of any civic organization from the Chamber of Commerce to the League of Women Voters. "Socialism" is a controversial term, but the desire to express one's individuality by control of the workplace is precisely the motive that inspires so many people to take the risk of opening small businesses, and that causes them to resent "socialistic" government regulation. Of course, other people prefer the security, benefits, and regular hours that come with the structured routine of a corporation, a government bureaucracy, or a large university law school. The drawback of "free self-activity" is that it is so difficult to justify requiring other people to pay for it.

Gerald Frug's The City as a Legal Concept ${ }^{97}$ is one of the few Critical articles to suggest anything concrete. Frug favors powerful local governments as the most hospitable forum for participatory democracy, but he earnestly assures us that this particular omelet can be made without breaking any eggs:

It should be emphasized that participatory democracy on the local level need not mean the tyranny of the majority over the mi-

quest, the subjugation of women, and human slavery are some of the elements Professor Parker would revise.

95. Gabel, supra note 21 , at 315.

96. Tushnet, The Dilemmas of Liberal Constitutionalism, 42 OHiO ST. L.J. 411, 424 (1981). But see id. at 425 ("The answer I give today would not necessarily be the one I would give were I a judge, for that fact itself would signal that political circumstances had changed drastically.").

What Tushnet might have in mind by "Socialism" is anybody's guess, because this playful writer frequently employs familiar words as terms of art. For example, he has recently cited as examples of legislative "tyranny" "a tax system skewed substantially against redistribution of wealth, a system of subsidies to political activity that at least perpetuates and perhaps magnifies the disparities of power that are occasioned by disparities in wealth, and a system of public assistance to those in need that is administered by a bureaucracy that degrades its supposed beneficiaries." Tushnet, Following the Rules Laid Down: A Critigue of Interpretivism and Neulral Principles, 96 HaRv. L. REv. 781, 788 n.19 (1983). Professor Tushnet has complained that he is frequently misunderstood, see Tushnet, stpra note 34, at 825-26; perhaps he could alleviate the problem by using words as other people do.

97. Frug, supra note 13. 
nority. Cities are units within the state, not the state itself; cities, like all individuals and entities within the state, could be subject to state-created legal restraints that protect individual rights. Nor does participatory democracy necessitate the frustration of national political objectives by local protectionism; participatory institutions, like others in society, could still remain subject to general regulation to achieve national goals. The liberal image of law as mediating between the need to protect the individual from communal coercion and the need to achieve communal goals could thus be retained even in the model of participatory democracy. ${ }^{98}$

Frug makes participatory democracy sound a lot like student government. There is to be plenty of bustle and debate, but the responsible authorities will make sure no serious harm is done.

I have already described Critical legal scholarship as ambivalent in its diagnosis of our social and personal ills, and, of course, uncertainty of diagnosis leads to uncertainty in the prescription of a remedy. There is a further problem with the remedy itself, and the vacuity of Critical scholarship when faced with the task of proposing remedies stems partly from a reluctance to come to grips with this problem. The issue can be put quite simply: If we assume that leftist political movements aim to create "socialism," and that "socialism" ineans something like individual self-determination within an ethic of cooperation, does this goal imply a centralization or a decentralization of power?

Not many years ago socialism meant nationalization-ownership and control of the economy by the national government. But government management of industry and agriculture has been tried on a large scale in many countries, and the results have not been exactly what the pioneers of socialism had hoped. Inequalities of wealth have no doubt been reduced, but the bureaucratic state provides no cure for alienation, competitive individualism, greed, power-seeking, or other ills previously associated with capitalism. Furthermore, bureaucracies operate "by the book," and therefore even the most benign bureaucracy is inherently hostile to individual selfdetermination. Anyone with experience in public employment cannot fail to be aware of this fact.

To escape the rigidity of bureaucracy, socialists must reduce the scale of economic and political organizations. Hence, they have been interested in worker control of individual factories, in small-scale cooperatives, and in semi-independent local geographical units where social cooperation might flourish. But how is a decentralized socialist

98. Id. at 1072 (footnotes omitted). 
society to prevent those small-scale units from adopting antisocialist policies? Some localities are sure to set up new hierarchies, or to refuse to share the wealth with the disadvantaged or the unproductive. If local units are permitted to trade with each other, market forces will again begin to operate. Unless there is pervasive control by a national bureaucracy, what is to prevent self-governing economic units from turning capitalist and attracting most of the movable capital and the most ambitious people?

It is not for me to say whether socialists should prefer the rigidities of bureaucracy or the risks of autonomy, but any socialist or "radical" author who evades the dilemma or attempts to straddle it is peddling sheer fantasy. Neither will it do to propose that a "balance" be struck between national and local authority. Power will inevitably gravitate to the authority that does the balancing.

One solution to the problem of how to maintain socialism without a stifling bureaucracy is to suppose that the "revolution" will bring about a dramatic transformation in human nature, after which competitive individualism will cease to be a problem. Socialism of this sort is often described as a secularized form of Messianic religion, and indeed it is not easy to avoid terms like "faith," "salvation," and "miracle" when discussing the transformation. That the miracle is to be performed by man without the help of God makes it all the more miraculous. There is a "religious" element in Critical scholarship in this sense. It is most explicit in the writing of Roberto Unger, who calls for a new "metaphysics" and pleads for God to speak to us. ${ }^{99}$ It is less explicit but equally present in parts of Duncan Kennedy's work. The "fundamental contradiction," which sounds very much like original sin, is to be attacked by an act of faith in the form of a political leap in the dark inspired by "faith and hope in humanity without the assurances of reason." 100 Kennedy does not promise "salvation," to be sure, but that is the word he chooses to describe what we need. ${ }^{101}$ This is the language of religion, the process of groping for something in which to believe.

In his 1982 Sobeloff lecture at the University of Maryland Law School, Kennedy paid capitalism a revealing left-handed compliment:

There is a sense in which there has never been a culture more the conscious and intelligent product of the mass of people-a more

99. R. Unger, KNowledge ANd Politics 295 (1975).

100. Kennedy, supra note 12 , at 212-13.

101. See text accompanying note 20 supra. 
democratic culture-than that of late capitalism. It just isn't plausible to attribute the spiritual vacuity and desolation of that culture [(or its vitality, openness, and heroic quality)] solely to "the profit motive," or even to the "cultural hegemony of the ruling class." There is as well a problem of mass error, of cultural error as judged against an asserted transcendent standard of the true, good and beautiful [ (a standard that aspires to be free of racist, sexist, and class blindness)]. ${ }^{102}$

One who criticizes the conscious and intelligent choice of the mass of people by a "transcendent" standard necessarily presupposes the existence of Someone or Something that transcends mere human wishes, that is "good" no matter how many people think otherwise. Kennedy puts the assertion tentatively and defensively, as befits one who is not prepared to name the transcendent source or to specify its characteristics, beyond that it has a mighty thirst for equality. But this apparent modesty should not deceive us. Kennedy aims to be a social activist, not merely an ivory tower mystic. People are supposed to take action against this mass cultural error by "doing left politics" in whatever situation they find themselves. If "left politics" means that a coterie of elite law school graduates is to correct the cultural and spiritual errors of the masses, I wonder what "right politics" can possibly be. ${ }^{103}$

102. Kennedy, Distributive and Patemalist Motives in Contract and Tort Law, With Special References to Compulsory Terms and Unegual Bargaining Power, 41 MD. L. REv. 563, 578 (1982).

Later in the same article, however, he asserts that this same capitalism "conspires to drive its constituent groups so far from each other that they can't communicate very well. It creates a situation in which the working class, the middle class and the welfare class, for example, inhabit incommensurable moral domains, and treat each other as Victorian missionaries treated South Sea islanders, or as Junkers treated German peasants, or as the Japanese treated early visitors from the West." Id. at 648 .

Marxist thinking habits must be hard to break. That social stratification exists does not mean that capitalism has caused or even worsened it. The very examples Kennedy gives suggest that capitalism breaks down preexisting social stratification by promoting cross-cultural communication.

I would also like to contest the assertion that the three named classes "inhabit incommensurable moral domains." Have you watched a professional football game lately, Professor Kennedy?

103. CLS members currently speak of a split between the "instrumentalists" and the "irrationalists" in their movement. According to an unsigned article appearing in the Lizard (a CLS newsletter edited by Duncan Kennedy and distributed at the January, 1984, AALS Convention in San Francisco), instrumentalists see legal rules as covertly furthering the efforts of certain groups (e.g., capitalists, whites, males) to dominate others. Different hierarchical orders require differing legal orders, so that "particular rules are needed . . . in developing capitalism, other rules in monopoly capitalism and so on." Lizard, Jan. 5, 1984, at 3. Peter Gabel's book review of Dworkin's Taking Rights Seriously, see Gabel, supra note 21, fits this pattern.

Irrationalists, on the other hand, find legal rules too indeterminate, incoherent, and marginal to qualify for an instrumentalist role. Law is "merely an instance of social mythologiz- 


\section{The affinity that Critical legal scholarship has for quasi-theologi- cal terms and concepts is not surprising. ${ }^{10 *}$ Marxism of the Critical}

ing," and "there is no 'true' analysis that comports with the way things really are, because there is no hard social reality separate from our social construction of meaning." Lizard, supra, at 4.

Since there is no ultimately rational way to think about or organize the world, there is no ultimate irrationalist program, no attempt to substitute "truth" for "ideology:" Only the message that every structure is provisional and none is necessary. When pressed, some irrationalists will offer a vague vision of transcending the self/ other contradiction in a festival of life where power is abolished and the social group is not held together by collective fantasies that it's ruled by abstractions external to the group, like law or the logic of economic production, but instead each member sees herself in the other and each contributes to the constant creation of the group, and unity is not imposed but lasts as long as the intersubjective zap continues.

Id.

Judging from their contribution to this Symposium issue, Peter Gabel and Duncan Kennedy have moved very far into irrationalist territory. Kennedy renounces the fundamental contradiction (in part because "conservatives like Phil Johnson" have made unholy use of it), the distinction between individualism and altruism, and just about every other distinction. The essential truth that these preliminary formulations were leading up to turns out to be that "Nothingness is the worm at the heart of being." Gabel \& Kennedy, Roll Over Beethoven, 36 STAN. L. REv. 1 (1984).

If that was all there was to it, what could I say but "Bon Voyage!"? But on the political platform, Kennedy still relies on conventional leftist categories that reek of reification. He "stands behind the ideals of Marxism" and supports the Sandinista government of Nicaragua, but mistrusts the Soviet Urion "because its political infrastructure has deviated too much frorn the ideal Marxist model." Kennedy, Profs Push Workplace Lefism, 77 Harv. L. Sch. Rec., Dec. 9, 1983, at 1, 15. Apparently, being an irrationalist doesn't mean giving up the collective fantasies that one happens to like, but why does one like one set of fantasies (Sandinistas, ideals of Marxism) instead of others (free elections, free enterprise)? Is irrationalism only for the pure in heart, i.e., "leftists"? But what could such a category possibly mean from an irrationalist perspective" When you think about it, Professor Kennedy, doesn't the distinction between left politics and right politics also disappear into that black hole at the heart of being?

104. "Transcendence" is secularized in Critical Theory by the following logic: Our real interests or wishes are those we would form in conditions of perfect freedom and knowledge, rather than in the conditions of oppression and false consciousness in which we actually live. The function of the Critical thinker is to envision what our desires would be in such ideal conditions, and then to show us how to achieve that state of affairs. Thus Kennedy's transcendent standard may be that of an idealized humanity rather than that of a supernatural being or force. $S_{e} e$ R. Geuss, The Idea of a Critical Theory: Habermas and the FRANKFURT SCHOOL 54 (1981).

I have no objection to this secular formulation, provided we understand that it overcomes none of the problems of theistic religion. "How do you or I know the will of God?" simply becomes "How do you or I know what people would want under ideal conditions or indeed what conditions are ideal?" The Critical thinker, like the priest, must expect to be asked, "Are you only claiming transcendent authority for your own wishes?"

The quotations I have chosen to support my characterization of the CLS movement as "religious " come from only two authors, albeit two of the movement's most influential members. I would say that Kennedy and Unger are simply more candid about a feature of the CLS world view that is implicit throughout the CLS writing. The most basic jargon of the CLS movement-false consciousness, mystification, and the like-exists to support a very 
variety can easily be restated as a theology: The famous Liberation Theology of Latin America is precisely such a hybrid. ${ }^{105}$ One might even say that the notion that religion and law are radically distinct categories is itself a pillar of liberal ideology, a pillar that Critical reflection upon the arbitrariness of the legal definition of "religion" tends to undermine. ${ }^{106}$ Religious questions have to do with our perceptions of ultimate reality, our sense of what life is really about.

simple proposition: "Whether or not people actually want participatory democracy (or egalitarian socialism, or whatever), they cught to want it because it is a very good thing. Furthermore, they would want it if their beliefs had not been perverted by the oppressive conditions in which we live." CLS simply places an idealized, and therefore nonexistent. humanity in the place of God as the source of a transcendent standard by which the desires of real human beings can be judged. The equivalent notion in theistic language is that "People ought to do the will of God whether they want to or not. Furthermore, they would want to do it if their wills had not been perverted by the effects of sin."

105. One author writing on Liberation Theology has asserted:

More and more, then, faith surfaces as a liberation praxis. Insofar as faith is the acceptance of the Father's love and a response to it, it goes right to the root of social injustice. The root of social injustice is sin, which ruptures our friendship with God and our brotherhood with other human beings. But the praxis of faith cannot bypass the mediating realities of history or avoid socio-political analyses of them. For sinfulness occurs in the negation of human beings as brothers and sisters, in oppressive structures created for the benefit of only a few, and in the plundering of nations, races, cultures, and social classes. Sin is the fundamental alienation which, for that very reason, cannot be grasped in itself. It is found only in concrete historical situations and specific embodiments of alienation. It is impossible for us to comprehend the one without the other.

Sin demands a radical liberation, which necessarily includes liberation of a political nature. Only by participating aggressively and effectively in the historical process of liberation can we point a finger at the basic alienation that underlies every partial form of alienation.

Gutierrez, Liberation Praxzs and Christian Faith, in Frontiers of Theology in Latin AMERICA 20-21 (Gibellini ed. 1979). Gustavo Gutierrez, author of A THEOLOGY OF LiBERATION (1973), is the most prominent of the Liberation Theologians.

106. See, e.g., Choper, Defining "Religion" in the First Amendment, 1982 U. ILL. L.F. 579 (1982). Choper begins by observing that '[g]iving the concept of 'religion' a precise meaning is a formidably complicated task," and that "the Supreme Court has never seriously discussed how this term should be defined." Id. at 579 . He concludes by proposing a "surely imperfect" definition that is "grounded in certain functional considerations and some historic values," and reassures the reader that the choice of definition is of very limited significance. Id. at $612-13$.

I would argue that defining "religion" is an intractable problem once one gets away from the customary categories of Protestant, Catholic, and Jew. For example, Marxism and Buddhism are somewhat parallel cases with respect to the distinction between religion and philosophy/ideology. In 1981, the Dalai Lama wrote that "among religions Buddhism is atheistic in the sense that a creator god is not accepted; rather, Buddhism presents a view of selfcreation, that one's own actions create one's life situations." Dalai Lama, Spiritual Contributions to Social Progress, Wall St. J., Oct. 29, 1981, at 30, col. 3. If a "religion" must be theistic, neither Buddhism nor Marxism qualifies. But if we adopt the more expansive definition of religion promulgated in United States v. Seeger, 380 U.S. 163 (1965) (belief occupying a place in one's life parallel to that filled by the orthodox belief in God), then both Marxism 
Such beliefs form our values, and law reflects those values. If there really is a God who judges human actions, or a fundamental contradiction, or a historical process that is inevitably taking us somewhere, or a "true consciousness" in comparison to which all differing world views are degrees of "false consciousness," it is only prudent to take that reality into account in everything we do. The rationalism of the Age of Enlightenment has not abolished religious issues, but rather has merely caused them to take refuge in secular language.

On the other hand, the realm of law and politics is the realm of power, of social obligations that are ultimately enforced by police, courts, and jails. The salvationist impulse can be extremely dangerous in this realm, never more so than when it comes disguised as something else. There is a kind of person who aspires to satisfy his spiritual needs, including his longing for a better world, by violently transforming the lives of other people. On the basis of the historical record, I would say this aspiration should be firmly discouraged. To his credit, Duncan Kennedy has warned us that the existence of evil within us "is not compatible with that sense of the purity of one's intention which seems often to have animated the enterprise of remaking the social world." 107 But when the radical fever is upon him, he seems to forget his own wisdom. ${ }^{108}$

\section{CONCLUUSION}

Reading a quantity of Critical legal scholarship for this Symposium has been an interesting and a frustrating experience for me. It has been interesting because the Critical scholars are concerned with truly important questions, and because there is a core of truth in their radical critique of liberal theory. It has been frustrating because at crucial points these writers invariably take refuge in a shallow Marxism or anarchism, or in some empty denunciation of "hierarchy" or endorsement of "equality." But equality is just as slippery a platform for radicals as it is for liberals. Equality is a platitudinous concept that practically everybody supports because it can be given any meaning we like. ${ }^{109}$ Capitalism, democratic socialism, Marxism, "human rights," utilitarianism, animal liberation, anarchism, and libertarianism can all be justified from the standpoint of

and Buddhism are religions. The label is controversial because, to a Marxist, "religion" is virtually synonymous with "delusion."

107. See text accompanying note 15 supra.

108. See notes 54,89 supra.

109. See Westen, The Emply Idea of Equality, 95 HARv, L. REV. 537 (1982). 
equality. Formal agreement on equality as a value masks the fact that we haven't a clue as to what is supposed to be equal to what, and in what way, or to what degree.

The seemingly sophisticated tendency of Critical scholars to see "politics" at the root of every practice is also unsatisfying. Politics deals with the accommodation and adjustment of claims backed by power, and to see nothing but politics in law is to adopt the claim of Thrasymachus that justice is the will of the stronger. ${ }^{110}$ That amounts to nihilism, which is a coherent position only if one is prepared to accept the implication that might makes right. It is clear that the Critical scholars do not want to accept that implication, which, after all, would make them very wrong indeed. They want to escape the impasse of nihilism by liberating themselves from an inherited burden of false consciousness that makes hard choices seem inevitable.

To my way of thinking that is a religious or spiritual aspiration, which is to say it takes us directly into that dangerous territory that liberal rationalism is most concerned to avoid. Marxists are also threatened by comparisons with religion, because they understandably fear that their theory may lose all credibility if it ceases to cloak itself in the mystique of science. Nonetheless, I would argue that clear thinking is furthered when we overcome our fear of addressing religious issues and of labelling them as such. First, describing the quest for the source of morals and values as "religious" encourages us to remember that "political" activity is pragmatic and that its successes are always limited and relative. From this perspective, "utopian" politics is a contradiction in terms. To demand utopian solutions is to engage in mysticism or holy war, not politics.

Second, labelling all quests for ideal solutions or for transcendent values as "religious" counteracts the single most mystifying concept of our time-the notion that there is a "scientific" solution to the problem of morality, an ideology or philosophy that can generate values out of purely natural materials and logic. Social Darwinism, Marxism, and various forms of psychoanalytic theory have been enormously successful in exploiting public credulity on this subject. Describing all imaginative speculation about ethics and justice as religion is my way of demystifying pseudoscientific prejudice. It makes it possible to ask which of all the religions or metaphysical systems provides the best place to plant our feet.

It is not my purpose to insist upon labels. Whether we call it 
religion, or politics, or psychology, or simply ideology, there is a widespread opinion that people need to be liberated from something, and that this is true even for citizens of those few countries that have the benefits of democratic constitutional government. Some might even say that it is true especially for people in those countries, because having the liberty to satisfy many of our desires may be experienced as a burden if we have the sense that we want the wrong thing, or don't know what we want. One hardly needs Marxism to be aware of that. After all, it was Alexander Solzhenitsyn who shocked the 1978 Harvard Commencement audience and the liberal rationalist media establishment by describing the "decline in courage," the legalistic selfishness, and the consequent "spiritual mediocrity" of Western democratic capitalism. "Mere freedom per se [i.e., political freedom and economic prosperity] does not in the least solve all the problems of human life and even adds a number of new ones."111

But what do we need to be liberated from and liberated to? From capitalism to socialism? One has to be blind to experience to place great hope in that kind of solution, even if one is unenthusiastic about capitalism. The Critical scholars are obviously desperate to find a better idea. (Critical legal historians write about the history of capitalism, not the history of socialism, and it is easy to see why.) There are a number of places one might look for the beginnings of a solution to the problem of what oppresses people when they have a relatively high degree of economic opportunity and a democratic constitutional government. Playing with Marxism, or getting lost in the farther reaches of German Idealistic philosophy, is not a promising way to start.

If the Critical scholars would only put Hegel, Habermas, Husserl, Heidegger, and Horkheimer back on the shelf for a while and turn their minds to something more basic, Critical jurisprudence would have a chance to evolve into self-critical jurisprudence. Then we might see wonderful things: humility instead of pretentiousness, humor instead of frivolity, and a willingness to step off the utopian pedestal and share the practical difficulties of the human condition. But now I'm being utopian.

111. A. Solzhenitsy', A WORld Split Apart 9, 15, 17, 19, 49 (1978). 
HeinOnline -- 36 Stan. L. Rev. 2921984 